\title{
The Presumption of Constitutionality
}

Joseph Eliot Magnet

Follow this and additional works at: http://digitalcommons.osgoode.yorku.ca/ohlj Article

\section{Citation Information}

Magnet, Joseph Eliot. "The Presumption of Constitutionality." Osgoode Hall Law Journal 18.1 (1980) : 87-145.

http://digitalcommons.osgoode.yorku.ca/ohlj/vol18/iss1/3

This Article is brought to you for free and open access by the Journals at Osgoode Digital Commons. It has been accepted for inclusion in Osgoode Hall Law Journal by an authorized editor of Osgoode Digital Commons. 


\section{THE PRESUMPTION OF CONSTITUTIONALITY}

By Joseph Eliot MAGNeT*

\section{CONTENTS}

I. INTRODUCTION ……................................................... 88

A. Pragmatism in Constitutional Law ..................................... 88

B. Implications of Pragmatism ............................................ 90

C. Constitutional Policy and Legislative Policy Distinguished ..... 92

II. CATEGORIES OF THE PRESUMPTION

A. Presumption of Regularity ................................................... 96

1. Legislative Intent ...................................................... 97

2. Legislative Declaration of Facts ….............................. 103

a) Rebuttable or Irrebuttable? ……………………........ 105

b) Changing Facts ………………............................ 110

c) Rational Basis ……......................................... 113

B. Canon of Construction ................................................... 116

1. Construction of the B.N.A. Act .................................... 116

2. Construction of the Challenged Act ............................. 120

C. Evidentiary Presumption of Fact ........................................ 121

1. The Presumption in Canada: New Directions ................ 121

2. Presumption of the Existence of All Necessary Facts ....... 127

3. Rational Connection ................................................. 128

III. OVERCOMING THE PRESUMPTION ……....................... 131

A. Position of the Attacker ................................................... 131

1. Judicial Notice .......................................................... 131

2. Proof of Facts at Trial ................................................. 134

3. Proof in Appellate Facta ….......................................... 137

4. Specialized Research Agencies ……............................... 138

B. Position of the Government ......................................... 139

C. Standard of Proof .......................................................... 141

1. Rational Connection .................................................. 141

2. Facts …............................................................. 143

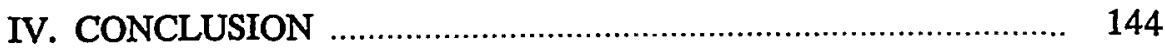

() Copyright, 1980, Joseph Eliot Magnet.

* Associate Professor, Faculty of Law, University of Ottawa. 


\section{INTRODUCTION}

\section{A. Pragmatism in Constitutional Law}

During hearings on the Davie Shipbuilding appeal ${ }^{1}$ in 1976 , the Canadian Supreme Court judges encountered a perplexing difficulty. It arose from evidence filed in the case: there were 123 volumes of evidence and no place to put them.

Stacked in the law clerk's quarters, nine sets of evidence (1107 volumes) blocked radiator heat; the clerk of process had not shelf space enough by half, and more materials arrived daily; moving the evidence about to find suitable storage created a manpower problem. Reading the evidence presented the most formidable challenge of all.

Although Davie Shipbuilding holds the record for most evidence filed in Supreme Court history, it is not unique. Davie Shipbuilding and like cases indicate a distinct change in the functions of modern courts. From tribunals of pure law, the courts have become largely tribunals of fact (or, in the case of appellate courts, interpreters of statutes). This increased concentration on factual findings has greatly slowed the pace of the courts. At the beginning of the nineteenth century Lord Ellenborough disposed of twenty cases a day; Lord Abinger somewhat later heard six or seven. By contrast, two is a job well done in any modern court; ${ }^{2}$ the Supreme Court of Canada averages 1.2 cases per day. Among the many reasons for this are the complexity and detail that factual issues present. A second reason is that factual material has to be appreciated against an elastic legal standard. The tribunal has to decide whether, in a tort case, the facts indicate reasonable conduct in the circumstances, or if, on construction of a particular contract, the facts amount to breach. To an increasing extent legal standards must be developed out of the case's individual particulars. Unlike the legal certainties of the nineteenth century, twentieth century justice has become personalized, or, more philosophically, pragmatic. ${ }^{3}$

Constitutional law in Canada has been remarkably resistant to this trend. Factual issues have been rare. Legal standards tend to the general; rarely has their articulation depended on individual facts and circumstances. Stare decisis, until very recently, ${ }^{4}$ has held.

If one surveys constitutional cases decided in the last ten years, it becomes apparent that things are changing here as well. Factual evidence 661.

1 Davie Shipbuilding Ltd. v. Cargill Grain Co., [1978] 1 S.C.R. 570, 91 D.L.R. (3d)

2 Atiyah, From Principles to Pragmatism: Changes in the Function of the Judicial Process and the Law, An Inaugural Lecture Delivered Before the University of Oxford on 17 Feb. 1978 (Oxford: Clarendon Press, 1978) at 14.

3 Id. at 15. Professor Atiyah's monograph, P.S.A., first drew the author's attention to this point.

4 McNamara Construction (Western) Ltd. v. The Queen, [1977] 2 S.C.R. 654, 75 D.L.R. (3d) 273; Reference re Agricultural Products Marketing Act (1978), 19 N.R. 361, 84 D.L.R. (3d) 257 (S.C.C.). 
was produced in impressive quantities in several cases. ${ }^{5}$ What makes the point even clearer is that the Supreme Court has adopted the practice of specifically calling for factual evidence in constitutional law decisions. ${ }^{6}$ The best example of this trend is presented by an Irish case, Ryan v. The Attorney General. ${ }^{7}$ In the Ryan case a claim of constitutional infirmity was asserted against an Act of the Oireachtas, ${ }^{8}$ which provided for compulsory fluoridation of public water supplies. It was said that the Act was obnoxious to the plaintiff's constitutional right of bodily integrity. ${ }^{9}$ The Court sifted through a formidable mass of technical data in order to ascertain whether fluoridation in fact involved risk to life of the citizenry or any special class of them. The Court had to weigh conflicting expert technical briefs and testimonies, and it is apparent that the Court undertook the task without the slightest hesitation and, perhaps, with a certain relish. The Irish Supreme Court gave a ruling based on the state of scientific knowledge then proved, and allowed that the constitutionality of the Act again could be called into question if and when scientific developments and knowledge changed. Ryan is the perfect example of a constitutional ruling that anticipates variation according to the circumstances. It illustrates in the starkest terms the movement toward a constitutional law tailored to individual facts, a personalized or pragmatic public law jurisprudence. ${ }^{10}$

${ }^{5}$ Reference re Agricultural Products Marketing Act, id.; Reference re Anti-Inflation Act, [1976] 2 S.C.R. 373, 68 D.L.R. (3d) 452; CIGOL v. Gov't of Sask., [1978] 2 S.C.R. 545, 80 D.L.R. (3d) 449; Central Canada Potash Co. v. Gov't of Sask., [1979] 1 S.C.R. 42, 88 D.L.R. (3d) 609.

B In In re the Board of Commerce Act, 1919, [1922] 1 A.C. 191 at 196, 60 D.L.R. 513 at 515 (P.C.), Viscount Haldane records how when the constitutional case was first stated by the Commerce Board for opinion of the Supreme Court, the Court "took the view that the case was defective, inasmuch as it did not contain a statement of concrete facts, out of which such questions arose." A fresh case had to be stated. In Reference re Anti-Inflation Act, id., the Court gave directions that factual data be produced by counsel in the facta, and procedures were specified for replying to the data. See also A.G. Man. v. Man. Egg and Poultry Ass'n, [1971] S.C.R. 689, 19 D.L.R. (3d) 169; Kruger v. The Queen, [1978] 1 S.C.R. 104, 75 D.L.R. (3d) 434, 34 C.C.C. (2d) 377; and Montcalm Construction Inc. v. Minimum Wage Comm'n (1979), 25 N.R. 1, 93 D.L.R. (3d) 641 (S.C.C.).

7 [1965] I.R. 294 (Sup. Ct.).

8 Health (Fluoridation of Water Supplies) Act, 1960; and Fluoridation of Water Supplies (Dublin) Regulations, 1962, S.I. 1962, No. 75.

${ }^{8}$ The Constitution of Ireland, 1937, does not create, by its terms, a right to bodily integrity. What it does create are certain fundamental rights. The plaintiff sought to spin out of the cluster of personal rights enumerated in art. 40(3) the specific right to bodily integrity.

10 Ryan, supra note 7, is not unique. Cases have arisen under the Australian constitution in which the constitutional ruling varied as the facts changed: see Armstrong v. State of Victoria (No. 2) (1957), 99 C.L.R. 28 (H.C. of Aust.); and Commonwealth Freighters Pty. Ltd. v. Sneddon (1959), 102 C.L.R. 280 (H.C. of Aust.). Professor Lane, Facts in Constitutional Law (1963), 37 Aust. L.J. 108 at 118, explains the Australian position this way:

A statute is passed on the basis of certain facts; when these facts change, the Act becomes inoperative or unconstitutional; and the court could be made aware of this change by the presentation of evidence. 


\section{B. Implications of Pragmatism}

All of this has great significance to constitutional law in general and to the presumption of constitutionality in particular. Constitutional questions are shifting off the axis of grand abstract disputes respecting who, as between federal and provincial governments, has exclusive constitutional jurisdiction over some immense field of law-making such as labour relations, ${ }^{11}$ language ${ }^{12}$ or interprovincial trade. ${ }^{13}$ More precise and discrete questions are being asked. The new orbit for constitutional litigation has a factual centre. The questions more typically are as to whether, as a matter of fact, a particular piece of challenged legislation unduly interferes with legitimate interests of the coordinate level of government or with the individual's fundamental freedoms. ${ }^{14}$

The change suggests that The British North America Act, 1867,10 will be seen to contain a much larger reserve of concurrent powers than heretofore has been the case. The doctrine of exclusive legislative powers will wither and decay. Abstract domains of law-making, in which one or the other level of government exclusively is competent, are giving up ground to factual disputes as to whether a particular challenged law bears a reasonable connection to an asserted head or catalogue of powers.

This is a development which in the paramountcy machinery of our constitutional law already has been completed. Our courts, in contrast to those of the United States ${ }^{16}$ and Australia, ${ }^{17}$ now refuse to supersede provincial law for mere abstract or theoretical conflict with an allegedly paramount federal statute. There must be "operating incompatibility" in the sense that compliance with a provincial statute implies breach of a federal statute in the particular circumstances. ${ }^{18}$ That is preeminently a question of fact. As Mr. Justice Beetz put it in Montcalm Construction Inc. v. Minimum Wage Commission:

11 Toronto Electric Comm'rs v. Snider, [1925] A.C. 396, [1925] 2 D.L.R. 5 (P.C.). 12 Jones v. A.G.N.B., [1975] 2 S.C.R. 182, 45 D.L.R. (3d) 583.

13 Citizens Ins. Co. v. Parsons (1881), 7 App. Cas. 96, 1 Cart. 265 (P.C.).

14 Montcalm Construction, supra note 6, converts a labour relations jurisdictional dispute into a question of fact; CIGOL, supra note 5 (per Dickson J., dissenting), treats a trade and commerce jurisdictional dispute as an issue of fact; Kruger, supra note 6, turns a constitutional issue respecting Indian land claims into an issue of fact; and in Man. Egg and Poultry Ass'n, supra note 6, Laskin J. lamented the absence of facts in the constitutional question presented.

1530 \& 31 Vict., c. 3 (U.K.).

16 Pennsylvania v. Nelson, 350 U.S. 497, 76 S. Ct. 477 (1956); California v. Zook, 336 U.S. 725, 69 S. Ct. 841 (1949).

17 Commonwealth of Australia Constitution Act, 1900, 63 \& 64 Vict., c. 12, s. 109 (Aust.); Ex parte McLean (1930), 43 C.L.R. 472 at 483 (H.C. of Aust.): Inconsistency "depends upon the intention of the paramount Legislature to express by its enactment, completely, exhaustively, or exclusively, what shall be the law governing the particular conduct or matter to which its attention is directed. When a Federal statute discloses such an intention, it is inconsistent with it for the law of a State to govern the same conduct or matter."

18 Smith v. The Queen, [1960] S.C.R. 776 at 800, 25 D.L.R. (2d) 225 at 246, 128 C.C.C. 145 at 167-68, per Martland J.; Mann v. The Queen, [1966] S.C.R. 238, 56 D.L.R. (2d) 1, [1966] 2 C.C.C. 273; Ross v. Registrar of Motor Vehicles, [1975] 1 S.C.R. 5, 42 D.L.R. (3d) 68, 14 C.C.C. (2d) 322; Bell v. A.G.P.E.I., [1975] 1 S.C.R. 
Montcalm ... argues in its factum that the federal Act ... "may" differ [in its effects] from those of provincial law. That is not good enough. Montcalm had to prove that federal and provincial law were in actual conflict for the purposes of this case. 18

Federal states seem to be characterized by two stages in their constitutional history. In the first stage, federalist disputes-grand jurisdictional battles between central and local governments-characterize the early lives of most federal states. There is, one supposes, a certain inevitability about this largely because of the generality of language characteristic of constitutional documents. Stage two is a later development characteristic of older federations. The United States offers the worthiest example. Federalist disputes occur much less frequently. The courts already have done their work; the more obvious questions are resolved. Within the judicially elaborated constitutional structure, concurrent access to law-making fields is the rule rather than the exception. In constitutional jurisprudence, attention shifts to protecting the citizen from governments rather than protecting one level of government from the other. Canada is entering this second phase of her constitutional history. ${ }^{20}$

If this view of the direction of our constitutional law is correct, certain propositions follow respecting the proper posture to be taken by the courts in federalist disputes. First, the judges positively should refrain from searching for the "true meaning" of the constitution. That approach leads to the drawing of neat but academic jurisdictional lines. By drawing impermeable borders around abstract legislative fields, such rulings encourage jealousy on the part of the "proprietor" government over its turf. The opportunity for jurisdictional tension or conflict is increased. Nothing is gained in the actual litigation. The more profitable inquiry is whether or not the particular challenged law is sustainable.

Second, the courts positively should eschew a priori or abstract theories of constitutional incompetence. The search for object and purpose or a fictitious legislative intent can be a remarkably unhelpful analytical exercise.

25, 42 D.L.R. (3d) 82, 14 C.C.C. (2d) 336; Montcalm Construction, supra note 6. See generally, Laskin, Occupying the Field: Paramountcy in Penal Legislation (1963), 41 Can. B. Rev. 234; Lederman, The Concurrent Operation of Federal and Provincial Laws in Canada (1963), 9 McGill L.J. 185; and Strayer, "The Flexibility of the B.N.A. Act," in Lloyd and McLeod, ed., Agenda 1970: Proposals for a Creative Politics (Toronto: Univ. of Toronto Press, 1970) at 197.

19 Supra note 6, at 15 (N.R.), 661 (D.L.R.). It has been settled law for many years that the burden of proving confict for paramountcy purposes is on the party asserting it: A.G. Can. v. A.G. Que., [1943] Que. K.B. 543, rev'd on other grounds, [1947] A.C. 33 (P.C.). Mr. Justice Beetz merely reaffirms that position here. The burden is best explained as a phenomenon associated with the presumption of constitutionality.

20 There are, however, several significant and particularly bitter exceptions. The jurisdictional disputes over resource control and communications are important stage one phenomena, but one would have thought that the Supreme Court could have dealt with some or all of these disputes in stage two (concurrent powers) terms. See CIGOL, supra note 5; Central Canada Potash, supra note 5; A.G. Que. v. Kellogg's Co. of Can., [1978] 2 S.C.R. 211, 83 D.L.R. (3d) 314; Capital Cities Communications Inc. v. C.R.T.C., [1978] 2 S.C.R. 141, 81 D.L.R. (3d) 609, 36 C.P.R. (2d) 1; and Dionne v. Public Service Bd., [1978] 2 S.C.R. 191, 83 D.L.R. (3d) 178. 
Where factual evidence can firmly establish the effect of the challenged law, that evidence is crucial to determination of constitutionality. All efforts should be made to set it before the court. If the law is operating, evidence of its actual performance would be a compelling consideration. Where the constitutional question takes form as a reference on proposed legislation, evidence as to the reasonable expectations of experts would be relevant. Third, the legislation should stand or fall only as a matter of fact in the circumstances. ${ }^{21}$ Broad constitutional rulings which carve out large and exclusive legislative fields independently of the actual facts at issue encourage federal tensions. Fourth, courts should apply unsparingly the presumption of constitutionality in federalist disputes. The presumption should be applied as an evidentiary presumption and not only as a presumption of regularity or a canon of construction. The judges ought to make clear to counsel attacking federal or provincial statutes that counsel must, where relevant, build an evidentiary record capable of overcoming any significant or disputed isue of fact. If counsel fails to present necessary facts, the presumption of constitutionality will defeat him on the constitutional issue.

\section{Constitutional Policy and Legislative Policy Distinguished}

This view of constitutional law, and the lively interest in the presumption of constitutionality that it implies, gathers strength from a philosophy of federalism in which considerations relevant to the formulation of policy are important. By this view, the court does have a very significant role to play in the formulation of constitutional policy. It is crucial, however, to realize that constitutional policy is not the same as legislative policy. Constitutional policy (as relevant to federalist disputes) involves power allocation; legislative policy involves the uses of power once allocated. ${ }^{22}$ Three questions are central to the making of constitutional policy. The court

21 This already is happening. A government frustrated by a ruling of constitutional incompetence on a particular law often tries again. Recent examples include the Government of Saskatchewan, which, frustrated in its efforts to tax oil profits by The Oil and Gas Conservation, Stabilization and Development Act, 1973, S.S. 1973-74, c. 72, as amended by S.S. $1973-74$, c. 73 , introduced retroactive legislation to accomplish the same purpose by a different taxing scheme: see The Oil Well Income Tax Act, 1978, S.S. $1977-78$, c. 26 . New Brunswick, finding its scheme to tax promotional materials (Social Services and Education Act, R.S.N.B. 1973, c. S-10, s. 4) frustrated by the Supreme Court of Canada in Simpsons-Sears Ltd. v. Prov. Sec'y of N.B., [1978] 2 S.C.R. 869 , 82 D.L.R. (3d) 321, has recently sought to accomplish the same purpose by amended legislation.

22 The distinction was grasped early in Canadian constitutional law. For example, in Union Colliery Co. of B.C. v. Bryden, [1899] A.C. 580 at 585 (P.C.), Lord Watson said:

It is the proper function of a court of law to determine what are the limits of the jurisdiction committed to them [Parliament and the Legislatures]; but, when that point has been settled, courts of law have no right whatever to inquire whether their jurisdiction has been exercised wisely or not.

However, the implications of the distinction have never fully been appreciated. In particular, it has never before been fully discerned that there are policy issues relevant to the judicial function of determining the limits of jurisdiction, and that such issues might overlap with what Lord Watson calls inquiry into the wisdom of legislation. 
must inquire: (1) Whether the interest advanced by the enacting legislature has a reasonable connection to that legislature's catalogue of powers, (2) whether the challenged law unduly interferes with the interests of the other level of government, and (3) whether, on consideration of the interests and interference involved, the challenged legislation ought to stand or fall.

Constitutional policy-making may often overlap with the process by which legislative policy is formulated. The existence of an alternative legislative scheme, equally effective but less obnoxious to interests of the other level of government, certainly would be relevant to the process of constitutional scrutiny explained above. But overlap does not imply congruence. The identification of sound constitutional policy does not necessarily follow the same method of inquiry nor use the same legal and social materials as does the discovery of sound legislative policy. That is why the court must be astute to respect the legislature's determination of legislative policy. This essential point was made early in United States constitutional history in Ogden v. Saunders, where Mr. Justice Washington said:

It is but a decent respect due to the wisdom ... of the legislative body, by which any law is passed, to presume in favor of its validity, until its violation of the constitution is proved beyond all reasonable doubt.23

The distinction between constitutional policy and legislative policy in part explains why courts engaged in the process of constitutional decision ought to have policy materials brought before them. They should have such materials pleaded and proved in evidence as are relevant to their task. Although this evidence will not be the same as that brought before the legislature, by reason of the different tasks involved, there will be overlap. ${ }^{24}$

23 Ogden v. Saunders, 25 U.S. (12 Wheat.) 212 at 270 (1827). The point is more fully elaborated by Professor Thayer in his masterful article, The Origin and Scope of the American Doctrine of Constitutional Law (1893-94), 7 Harv. L. Rev. 129 at 152 as follows:

The judges were allowed, indirectly and in a degree, the power to revise the action of other departments and to pronounce it null. In simple truth, while this is a mere judicial function, it involves, owing to the subject-matter with which it deals, taking a part, a secondary part, in the political conduct of government. If that be so, then the judges must apply methods and principles that befit their task. In such a work there can be no permanent or fitting modus vivendi between the different departments unless each is sure of the full co-operation of the others, so long as its own action conforms to any reasonable and fairly permissible view of its constitutional power. The ultimate arbiter of what is rational and permissible is indeed always the courts, so far as litigated cases bring the question before them. This leaves to our courts a great and stately jurisdiction. It will only imperil the whole of it if it is sought to give them more. They must not step into the shoes of the law-maker....

24 The overlap is expected to be much greater when the constitutional issue involves fundamental freedoms protected under a Bill of Rights. Unlike federalist disputes, Bill of Rights issues are concerned with limitations on governmental power. The sole question is whether the law itself advances a sufficiently critical governmental interest. Thus, the wisdom of legislative policy is more directly called into question. Herein lies the explanation why American courts deal in policy questions and materials which, to a Canadian legal mind, oftentimes seem unthinkable. If our Bill of Rights is entrenched, or as it matures in its present form, the inevitable drift of our constitutional jurisprudence must be in this direction. 
To assist in bringing policy materials before the court, the presumption of constitutionality ought to be rigorously applied in favour of the legislature's determination of policy. This does not mean that the litigant challenging the validity of any law in the federalist dispute context has to show that such law is unwise. What the presumption requires him to show is that, as a matter of constitutional policy, the law is unwise (or invalid) beyond all rational doubt in that the interference produced is intolerable considering the interest advanced.

Numerous Canadian judges have stated that in constitutional litigation courts have no legitimate authority to interfere with legislative determination of policy.25 Many explanations of this self-imposed restraint have been given. ${ }^{26}$ Those who advocate judicial restraint in policy matters have never considered the implications of a distinction between constitutional policy and legislative policy. ${ }^{27}$ The plea for judicial restraint has assumed that the

25 The most recent statement to this effect is by Morrow J.A. in Reference re Proposed Legislation Concerning Leased Premises and Tenancy Agreements (1979), 89 D.L.R. (3d) 460 (Alta. S.C. App. Div.) at 469: "We certainly, as a court, cannot get into the area of policy ...."

26 See the debate on this point between Professor Laskin (as he then was) and $\mathrm{Mr}$. Mundell: Mundell, Tests for Validity of Legislation Under the British North America Act (1954), 32 Can. B. Rev. 813; Laskin, Tests for the Validity of Legislation: What's the "Matter"? (1955), 11 U. Toronto L.J. 114; and Mundell, Tests for Validity of Legislation Under The British North America Act: A Reply to Professor Laskin (1955), 33 Can. B. Rev. 915.

27 With great respect, a good example of confusion between constitutional and legislative policy-making is given in McWhinney, Federal Supreme Courts and Constitutional Review (1967), 45 Can. B. Rev. 578 at 586. Professor McWhinney writes:

As to the Privy Council and its record of interpretation of the Canadian Constitution, my criticism had been directed specifically to the failure of the Privy Council frankly to acknowledge and admit, in its formal opinions accompanying its decicisions, that it was engaging in constitutional elaborations that were neither expressly warranted by the text of the constitution, nor supported by the original historical intentions of the Founding Fathers of the constitution, in reaching the results that the Privy Council did, in the period from 1896 onwards, in relation to social and economic planning legislation and Dominion-provincial relations generally. The judicial policy-maker surely has certain obligations of public candour, in order to expose the judicial policy choices to the democratic corrective of public discussion and criticism. The failure of the Privy Council, in relation to the Canadian Constitution, to be frank and explicit as to the policy bases of its opinions, meant that the reasons for the actual policy choices too often remained obscured and concealed, with the policy considerations necessarily operating then as "inarticulate major premises" to the final decision. And the failure to articulate these same policy bases meant, in turn, that the judges were not directly assisted by counsel, through the Brandeis Brief technique of bringing social and economic facts before the court, or otherwise, in the building of an appropriate factual record that might inform and assist a judicial conclusion on complex social and economic issues. If we had judicial policy-making on the part of the Privy Council in relation to the Canadian Constitution, in the period from 1896 onwards, it was, necessarily, because of these very omissions, a species of policy-making in the dark,-at best, loosely impressionistic and in the end rather hit-and-miss.

There is, I think, an important difference between "social and economic planning legislation" and "Dominion-provincial relations generally" that this passage does not grasp. "Social and economic planning legislation" is for the legislature as a matter of legislative 
presumption of constitutionality aids its cause. The result of this thinking has been unfortunate.

In A.G. Ont. v. A.G. Can., Earl Loreburn L.C. suggested one reason why policy matters were for the legislature and not for the court; it must be presumed, he said, that the legislature considered all relevant policies:

Such considerations are proper, no doubt, to be weighed by those who make and by those who administer the laws of Canada, nor is any Court of law entitled to suppose that they have not been or will not be duly so weighed. So far as it is a matter of wisdom or policy, it is for the determination of the Parliament.... It cannot be too strongly put that with the wisdom or expediency or policy of an Act, lawfully passed, no Court has a word to say. All, therefore, that their Lordships can consider ... is whether ... this Act is outside the authority of the Canadian Parliament, which is purely a question of the constitutional law of Canada.28

The presumption of constitutionality is applied by the Lord Chancellor as a presumption of regularity. So used, the presumption excludes the court from developing policy perspectives on the immediate question. The court presumes that the legislature already has done so; further scrutiny is not a proper judicial task.

However, the distinction between constitutional and legislative policy is not drawn. Both are excluded from judicial consideration by the blunt approach taken. Failure to make the relevant distinction enables the presumption of constitutionality to be pressed into service to advance a philosophy of judicial timidity in policy matters.

A.G. Ont. v. A.G. Can. suggests a second point worthy of notice. The question of constitutional validity is treated as a question of pure law. Factual materials thereby become irrelevant. Restricted to a presumption of regularity, the presumption of constitutionality offers no resistance to this formulation of the problem. The result is that both factual and policy materials are excluded from the court's consideration. This implies that an abstract legal answer necessarily will be forthcoming from the court. Such abstract answers have a tendency to be broad.

This treatment of the presumption of constitutionality and the constitutional jurisprudence that it engenders has been extremely damaging to our constitutional law. Today, it is of exceptional importance that the different senses in which the presumption of constitutionality doctrine is used be distinguished, and that more sophisticated use be made of the tool. Canadian constitutional law is developing and must develop in the 1980's and 1990's a heightened sensitivity to issues of constitutional policy and appreciation of constitutional facts. A sound theory of the presumption of

policy; "Dominion-provincial relations generally" are for the courts when political and administrative channels break down-i.e., when asked. The distinction takes on added relevance in the Canadian context where social and economic planning legislation was tested in the context of a constitution without a Bill of Rights and which pays respect to the theory of Parliamentary Sovereignty. Thus, the issue in Canada during the thirties, unlike the United States, was a pure federalist dispute-a question of power allocation. 28 [1912] A.C. 571 at 583, 3 D.I.R. 509 at 512-13 (P.C.). 
constitutionality is of central importance to a renewed and modern constitutional jurisprudence. To that theory we must now turn.

What follows is an examination of the presumption of constitutionality under three different categories. Each category suggests a very different sense, and implies a distinct class of cases to which the presumption is relevant. The separate branches of the presumption of constitutionality are: (1) a presumption of regularity, (2) a canon of construction, and (3) a true evidentiary presumption of fact.

\section{CATEGORIES OF THE PRESUMPTION}

\section{A. Presumption of Regularity}

" [O]mnia praesumuntur solemniter esse acta"-all things are presumed to have been done rightly. ${ }^{29}$ Apply this homely maxim to the determination of constitutional validity and its prim and proper certitudes waver. Does the presumption of regularity refer to procedural regularity? Does it refer to substantive jurisdictional regularity, or does it mean that all factual preconditions are presumed to have been satisfied? To take an example: section 54 of The British North America Act, 1867, provides that:

It shall not be lawful for the House of Commons to adopt or pass any Vote, Resolution, Address, or Bill for the Appropriation of any Part of the Public Revenue, or of any Tax or Impost, to any Purpose that has not been first recommended to that House by Message of the Governor General in the Session in which such Vote, Resolution, Address, or Bill is proposed. ${ }^{30}$

Suppose a particular taxing measure is attacked for want of compliance with section 54. What is the effect of omnia praesumuntur solemniter esse acta? Does it translate into a presumption that the section 54 procedure was followed? Is it a presumption that the House of Commons rules ${ }^{31}$ for introducing taxing bills as a matter of law substantively comply with section 54 , or does the presumption assist with an answer to the now open question of whether failure to comply with section 54 cannot be judicially reviewed as being a point of parliamentary procedure cognizable by the House of Commons alone? ${ }^{32}$

Such ambiguity does not invite precise application. The Supreme Court, when this very issue was presented for consideration, avoided not only the constitutional question, but ducked the presumption as well. ${ }^{.33}$

29 Co. Litt. 6.b. Actually Lord Coke gives several versions of the maxim: "Omnia praesumuntur legitime facta, donec probetur in contrarium," op. cit. at 232.b.; and "Omnia praesumuntur rite et solemnitas esse acta donec probetur in contrarium," op. cit. at 232. See also Brown's Maxims, at 944: "Omnia rite acta praesumuntur." In Beacom v. Robison, $157 \mathrm{~Pa}$. Super. 515 at 521, 43 Atl. (2d) 640 at 643 (1945), the Pennsylvania Supreme Court stated: "[T]he doctrine of omnia praesumuntur rite esse acta, [is a] maxim [which] appears in various forms, but all are approximated in the language that a prima facie presumption of the regularity of the acts of public officers exists until the contrary appears."

$3030 \& 31$ Vict., c. 3 (U.K.).

31 Can. H. of C. Standing Orders, s. 62(1), 1969.

32 The last point is discussed by Laskin C.J.C. in Reference re Agricultural Products Marketing Act, supra note 4, at 395-96 (N.R.), 278-79 (D.L.R.).

33 Id. 
It is necessary to distinguish two separate senses in which the presumption of regularity operates. It may shed light on (1) the issue of legislative intent or (2) the issue of legislative declarations of facts.

\section{Legislative Intent}

Traditionally, Canadian courts, in answering questions as to constitutional validity, examine the object and purpose of a challenged statute. In one sense (but only one) object and purpose go to legislative intent: the enacting legislature must have intended to pursue a regulatory motive within its substantive jurisdictional capacity. ${ }^{34}$ The object and purpose test looks to the result that the enacting legislature hoped to achieve. As explained by Lord Maugham in the Bank Taxation Reference:

A closely similar matter may call for consideration, namely, the object or purpose of the Act in question.... It is not competent either for the Dominion or a Province under the guise, or the pretence, or in the form of an exercise of its own powers, to carry out an object which is beyond its powers. ....35

Conceived as a matter of legislative intent, it is clear that the object and purpose test is subjective. That conclusion is reinforced by Lord Maugham's statement. It is the subjective intent of an incorporeal entity. ${ }^{36}$ It may be that the object and purpose test simpliciter is an insufficient foundation upon which to ground constitutional decision, ${ }^{37}$ but that does not mean that it

84 Mr. Justice Duff in A.G. Ont. v. Reciprocal Insurers, [1924] A.C. 328 at 338, [1924] 1 D.L.R. 789 at 795, 41 C.C.C. 336 at 343-44 (P.C.), explained Union Colliery, supra note 22 , as a case where an improper legislative motive invalidated the challenged law. A second sense in which object and purpose are used is explained by Mundell, Tests for Validity of Legislation Under the British North America Act, supra note 26, at 832.

35 A.G. Alta. v. A.G. Can., [1939] A.C. 117 at 130, [1938] 4 D.L.R. 433 at 439 (P.C.) [hereinafter Bank Taxation Reference]. Mundell, in Tests for Validity of Legislation Under the British North America Act, id. at 828, explained the point this way:

Control and regulation .... are undertaken with some object or aim in view, to achieve some results in connection with the things, activities or concepts described in the "matter." It is this object or aim that constitutes Parliament's purpose.

In Tests for the Validity of Legislation: What's the "Matter"?, supra note 26, Professor Laskin (as he then was) expressed the opinion, at 115, that Mr. Mundell displayed a "naïvetê" about constitutional law.

30 Bank Taxation Reference, id. at 131 (A.C.), 439 (D.L.R.): "It must be remembered that the object or purpose of the Act, in so far as it does not plainly appear from its terms and its probable effect, is that of an incorporeal entity, namely, the Legislature...." Mr. Mundell made the same point: Tests for Validity of Legislation Under the British North America Act, id. at 832:

We must then look also to the state of mind of Parliament when enacting the law, to ascertain the motive that impelled Parliament to provide for the control or regulation brought about by the legislation and with what matter it is connected. This test is subjective.

37 Strayer, Judicial Review of Legislation in Canada (Toronto: Univ. of Toronto Press, 1968) at 16 downplays the significance of legislative intent considerably. His point is that:

[T] In the majority of cases the two may be identical. But in the crucial cases the court must see what the statute really does, not what its framers intended it to do.... 
is not a relevant consideration. In Co-operative Committee on Japanese Canadians v. A.G. Can., Lord Wright made it clear that an illegal purpose, as a matter of subjective legislative intent, would upset a challenged statute:

Their Lordships do not doubt the proposition that an exercise of the power for an unauthorized purpose would be invalid, and the only question is whether there is apparent any matter which justifies the judiciary in coming to the conclusion that the power was in fact exercised for an unauthorized purpose. In their Lordships' opinion there is not. The first three sub-sections of s. 2 no doubt deal with the matter which primarily engaged the attention of the Governor in Council, but it is not in their Lordships' view a proper inference from the terms of those subsections that the Governor in Council did not also deem it necessary or advisable for the security, defence, peace, order and welfare of Canada that the wives and children under sixteen of deportees should against their will also be liable to deportation. ${ }^{38}$

A presumption of regularity as applied to the issue of subjective legislative intent can mean only that the court assumes that the legislature acted with the requisite object and purpose and not with any illegal end in view. That point was made in a public law context by Lord Pearson in McEldowney v. Forde:

When the Minister has made a regulation, and purports to have it made under s. $1(3)$ of the Act, the presumption of regularity (omnia praesumuntur rite esse acta) applies and the regulation is assumed prima facie to be intra vires. But if the validity of the regulation ... was made otherwise than for the specified purposes, the courts will have to decide this issue, however difficult the task may bo for them in some circumstances. ${ }^{39}$

The point is old and well established in the Canadian constitutional context. A nineteenth century British Columbia court put it this way:

[T] he Provincial Legislature in purporting to give appellate jurisdiction must be presumed to have contemplated such matters only as were within its own power, and not such matters as were expressly removed from its regulation.40

That holding was sharpened and reinforced by Mr. Justice Fauteux in Reference Re Farm Products Marketing Act (Ont.) who said: "There is a presumptio juris as to the existence of the bona fide intention of a legislative body to confine itself to its own sphere...."11

How may the presumption of regular legislative intent-the intention to effect a legal object and purpose-be overcome? In administrative law cases, the courts have had no hesitation in reviewing factual evidence, including statements or letters by the authorities concerned, to determine the regularity of the authority's legislative or administrative intent. In Roncarelli v. Duplessis, ${ }^{42}$ Martland J. noted that cancellation of a liquor licence in pursuit of purposes unrelated to those of the relevant Alcoholic Liquor Act voided the administrative action. The intent of the cancelling

38 [1947] A.C. 87 at 107-08, [1947] 1 D.L.R. 577 at 591-92 (P.C.).

39 [1971] A.C. 632 at 655, [1969] 3 W.L.R. 179 at 197, [1969] 2 All E.R. 1039 at 1066 (H.L.).

40 Scott v. Scott (1891), 4 B.C.R. 316 at 319; see also Reference re Section 31 of the Municipal District Act Amendment Act, 1941, [1943] S.C.R. 295, [1943] 3 D.L.R. 145.

41 [1957] S.C.R. 198 at 255, 7 D.L.R. (2d) 257 at 311.

42 [1959] S.C.R. 121 at 156, 16 D.L.R. (2d) 689 at 742. 
authority was proved by evidence. In $R e$ Doctors Hospital and Minister of Health, ${ }^{43}$ an Order-in-Council revoking approval of Doctors Hospital as a statutory "public hospital" was attacked. The Court held that since the order had been made with the intent of saving public moneys, a purpose not contemplated by the parent statute, the order could not stand. In Re Heppner and Minister of Environment, ${ }^{44}$ the Alberta Court of Appeal applied a presumption of regularity to subordinate legislation establishing restricted development areas to control development detrimental to the environment. On affirmative proof, including letters of the relevant minister and his assistant deputy, that the minister's intent was to establish a transportation and utility corridor, the legislation was struck down. The point to notice is that in each of these cases, the presumption of a regular legislative or administrative intent was overcome by actual evidence to the contrary on the specific point of intention. In an administrative law setting, "The admissibility of ... [factual] evidence [on the issue of legislative intent] ... seems so clear as not to require authority. ..."4s

The transposition of the administrative law principle to a constitutional context is problematic. In the administrative law cases, the issue of intent concerns the intent of a specific person. In the constitutional cases, the issue of intent concerns the legislature, an incorporeal body made up of hundreds of persons. It may be said that such a body, like a corporation, is a legal fiction and has no intention in the relevant sense. It would follow that legislative intent, in the constitutional setting, is a hollow concept.

Largely in consideration of this argument, Canadian courts have developed the rule that, in scrutinizing legislative intent for the purpose of determining constitutional validity, statements by members of the legislature during passage of the challenged Act are irrelevant and inadmissible. ${ }^{46}$

43 (1976), 12 O.R. (2d) 164, 68 D.L.R. (3d) 220 (H.C.).

44 (1978), 80 D.L.R. (3d) 112, 6 A.R. 154 (Alta. S.C. App. Div.).

45 LaRush v. Metropolitan Toronto and Region Conservation Auth., [1968] 1 O.R. 300 at 307, 66 D.L.R. (2d) 310 at $316-17$ (C.A.).

${ }^{46}$ Toronto Ry. Co. v. The Queen (1894), 4 Ex. C.R. 262 at 270; Gosselin v. The King (1903), 33 S.C.R. 255. In Texada Mines Ltd. v. A.G.B.C., [1960] S.C.R. 713 at 720, 24 D.L.R. (2d) 81 at 87, the Court said this in obiter:

While that learned judge ... referred to certain statements purporting to have been made by the Premier of the Province and the Minister of Mines to the effect that the legislation was designed to discourage the export of iron ore ... he made it clear that he came to his conclusion without reference to this. That such a statement had been made was not proven at the trial and had the evidence been tendered it would, no doubt, have been rejected as inadmissible.

The point was fortified by the Court in A.G. Can. v. Reader's Digest A.ss'n, [1961] S.C.R. 775 at 792,30 D.L.R. (2d) 296 at 311:

It ... is clear on the authorities that the statement of the Minister in introducing the bill would be inadmissible in aid of the interpretation of the statute.... I can discern no difference in principle to afford a sufficient reason for holding it to be admissible where, the words of the statute being plain, it is sought to show that Parliament was encroaching upon a field committed exclusively to the provincial legislature.

Saumur v. A.G. Que., [1963] B.R. 116 at 123, aff'd on other grounds, [1964] S.C.R. 252; B.C. Power Corp. v. A.G.B.C. (1963), 47 D.L.R. (2d) 633 at 733-34, 44 W.W.R. 65 
Several explanations of the rule have been put forward. Strayer has argued that the rule is sound because legislative motive is irrelevant to constitutional validity: "The essential factual issue here is that of effect...."47 More convincingly, it has been argued that, considering the way in which the Canadian process of enactment differs from that of the United States, "Hansard gives no convincing proof of what the government intended ...".48 Moreover, by allowing ambiguities in the statute to be resolved by statements in the legislature, ministers would be given power in effect to legislate indirectly by making such statements. "Cabinets already have powers enough without having this added unto them."49

If this rule and associated explanations are sound, several wrinkles develop in the presumption of regularity as applied to the issue of legislative intent. If the presumption applies and the relevant factual evidence as to intent cannot be brought forward in rebuttal, we reach an impasse. The difficulty is not mitigated by the point that factual evidence may be brought forward to show the effect of the statute. That evidence demonstrates object and purpose in the objective sense. It casts no light on object and purpose in the subjective sense. One is driven, therefore, to one of four conclusions. Either (1) the presumption of regularity, as applied to the issue of subjective legislative intent, is irrebuttable; (2) the presumption does not apply to the issue of legislative intent; (3) the issue of legislative intent is irrelevant to the process of constitutional decision; or (4) the rule against admissibility of members' statements is wrong.

Alternative (1) may be rejected out of hand. The many statements by Canadian judges that legislatures may not effect colourable purposes under the guise of acting within their own powers, ${ }^{60}$ or by doing indirectly that which they cannot do directly, ${ }^{51}$ make such a suggestion untenable. For the same reason, alternative (3) must be rejected. There are too many

at 172 (B.C.S.C.). See generally MacDonald, Constitutional Interpretation and Extrinsic Evidence (1939), 17 Can. B. Rev. 77. However, in Bank Taxation Reference, supra note 35, at 131 (A.C.), 439 (D.L.R.), Lord Maugham said: "[T]he object and purpose of the Act, ... is that of an incorporeal entity, namely, the Legislature, and, generally speaking, the speeches of individuals would have little evidential weight." This suggests not a rule going to inadmissibility, but a caution as to weight. Similarly, the Court in A.G. Can. v. Reader's Digest Ass'n., op. cit. at 792 (S.C.R.), 311 (D.L.R.), says that ministerial statements would be inadmissible when "the words of the statute [are] plain...." Presumably, if the words of the statute are not plain, the rule would be otherwise.

47 Supra note 37 , at 166.

48 Corry, The Use of Legislative History in the Interpretation of Statutes (1954), 32 Can. B. Rev. 624 at 633. See also an article by Driedger, The Preparation of Legislation (1953), 31 Can. B. Rev. 33, for discussion of the Canadian and American legislative process.

49 Corry, id. at 637.

50 E.g., Re Wolfenden (1971), 21 D.L.R. (3d) 118 at 125-26, [1971] 5 W.W.R. 168 at 177 (B.C.S.C.), aff'd sub nom. Min. of Finance for B.C. v. First National Bank of Nevada, [1975] 1 S.C.R. 525, 40 D.L.R. (3d) 739, aff'g (1972), 28 D.L.R. (3d) 756 (B.C.C.A.). 1 at 10 .

51 Amax Potash Ltd. v. Gov't of Sask., [1977] 2 S.C.R. 576 at 590, 71 D.L.R. (3d) 
cases that have grounded constitutional decision on legislative intent to pretend that the doctrine does not exist. ${ }^{52}$

If the presumption does not apply to the issue of legislative intent (alternative (2)), then legislative intent must really be irrelevant. There would be no presumption to indicate whether the intent was or was not regular and by the rule previously stated no evidence could be led to discover the actual intent. Thus, the intent could be neither known nor presumed; clearly, in that case, it could not influence the constitutional decision. However, for the reasons given for rejecting alternatives (1) and (3) - that such a conclusion cuts too sharply across the decided cases ${ }^{53}$ - this result appears unwarranted.

This leaves alternative (4), which postulates that the rule against admissibility of statements by members of the legislature as an aid in determining constitutionality is wrong. Alternative (4) also cuts against the decided cases, but it does so assisted by very sharp criticism of such Canadian cases as exist, ${ }^{54}$ and by the example of a flourishing but contrary rule in the United States. ${ }^{55}$ Is alternative (4) tenable?

62 Bank Taxation Reference, supra note 35; A.G. Ont. v. Reciprocal Insurers, supra note 34; In re Insurance Act of Canada, [1932] A.C. 41, [1932] 1 D.L.R. 97, [1931] 3 W.W.R. 689, 53 Que. K.B. 34 (P.C.); A.G. Sask. v. A.G. Can., [1949] A.C. 110, [1949] 2 D.L.R. 145. Although Professor Hogg in Constitutional Law of Canada, (Toronto: Carswell, 1977) at 87 attempts to explain away the issue of subjective legislative intent by saying that "[The colourability doctrine] ... simply means that "form is not controlling in the determination of essential character'" That seems a partial explanation only; what the courts have said suggests something beyond mere form.

53 Supra notes 50-51. See also Reference re Farm Products Marketing Act (Ont.), supra note 41, per Fauteux J. For a collection of English cases stating the rule, see Annotation, Resort to Constitutional or Legislative Debates, Committee Reports, Journals, Etc., as Aid in Construction of Constitution or Statute (1931), 70 A.L.R. 5 at 14.

54 Davis, Legislative History and the Wheat Board Case (1953), 31 Can. B. Rev. 1 (courts should look at statements by members of the legislature in construing Acts of Parliament: an administrative law context); Milner, The Use of Legislative History (1953), 31 Can. B. Rev. 228; Kilgour, The Rule Against the Use of Legislative History: "Canon of Construction or Counsel of Caution"? (1952), 30 Can. B. Rev. 769. See contra: MacQuarrie, The Use of Legislative History (1952), 30 Can. B. Rev. 958; Corry, supra note 48; and Strayer, supra note 37, at 165-66. The author ought to add a personal view, which developed while law-clerking at the Supreme Court of Canada close to the process of judicial decisions, that judicially created per se doctrines such as this are really toothless tigers. They survive only so long as useful. If it becomes useful to scrap the rule in a particular decision, it will go, and nicely too. The rule against admissibility of extrinsic aids in constitutional construction (very similar to the rule against admissibility of members' statements) was exhaustively reviewed by J. tenBroek, $A d$ missibility and Use by the United States Supreme Court of Extrinsic Aids in Constitutional Construction (1938), 27 Cal. L. Rev. 287 at 308, who concluded:

Like all the other instruments of the Court its ultimate utility depends on its merits as an instrument of persuasion in that most indispensable of judicial functions, namely, writing the most convincing opinion possible under the circumstances. We must conclude, the test of the invocability of the rule being a matter of forensic expediency, that collateral materials may be introduced in all cases in which they tend to assist the Court in supporting the decision reached.

53 , at 6 .

${ }^{5}$ See Annotation; Resort to Constitutional or Legislative Debates, Etc., supra note 
Assume that constitutional attack is made against a particular conditional grant from the federal government to the provinces. The grant is to support post-secondary education. Conditions attached to the grant require that qualifying provinces maintain freedom of language choice for certain residents (as defined in the granting act) in primary education. The Province of Quebec complains that the conditions force it to reverse its language and education policies and to repeal certain recent legislation. Its submission in the litigation is against the conditions only on the theory that the federal government, by ostensibly legislating in relation to the public debt and property, ${ }^{56}$ is colourably attempting to formulate policy in relation to education and language.

Suppose further that Hansard reveals that, during debate on the appropriation bill, the Prime Minister made the point that the bill was Ottawa's response to Quebec's language policies and legislation. "It is our hope," he said, "that the provinces will respond to our legislation by amending their language laws." The opposition leaders record their approval. Ought such evidence crucial to the constitutional issue be ruled inadmissible?

If there is ambiguity in the statute or as its constitutional validity and evidence relevant to resolving that ambiguity having probative value is brought forward, the evidence ought to be admitted. Evidence of members' statements on the example contemplated is relevant and has probative value. The only useful question would be as to weight. The weight given to the evidence should vary with its nature and the circumstances. It is unsubtle to rule per se that such evidence is inadmissible. ${ }^{57}$

The above example seeks to support the admissibility of evidence suggesting that the bill was passed in pursuit of regulatory purposes beyond the enacting government's powers. This position gathers strength from remarks made by Mr. Justice Beetz in Reference re Anti-Inflation Act; in that landmark of modern constitutional law, Mr. Justice Beetz referred to speeches by various Ministers in Parliament as reproduced in Hansard: "in order not to construe and apply the provisions of the Anti-Inflation Act, but to ascertain its constitutional pivot." 58

The purpose of this exercise was to support the conclusion that no emergency existed sufficient to trigger Parliament's extraordinary power. As Mr. Justice Beetz explained:

56 The British North America Act, 1867, 30 \& 31 Vict., c. 3, s. 91 (1A), as am. by 1949 , 13 Geo. 6, c. 81 (U.K.). See generally, Magnet, The Constitutional Distribution of Taxation Powers in Canada (1978), 10 Ottawa L. Rev. 473 at $480-84$ for amplification of the constitutional questions posed by this example.

57 See, for additional arguments, Constitutional Law-Admissibility of Evidence as to Effect of Impugned Statute as Aid in Determining Validity (1940), 18 Can. B. Rev. 657 at 658-59. Moreover, there is Canadian authority which supports this conclusion: In Bank Taxation Reference, supra note 35, (A.C.), 439 (D.L.R.), Lord Maugham said, "[G]enerally speaking, the speeches of individuals would have little evidential weight [in determination of object and purpose]." At face value admissibility is assumed with a caution as to weight.

${ }^{58}$ Reference re Anti-Inflation Act, supra note 5, at 470 (S.C.R.), 534 (D.L.R.). 
Reliance upon those statements is not essential to my conclusions. However, they reinforce my opinion that the Anti-Inflation Act was enacted in this form because it was believed, erroneously, that Parliament had the ordinary power to enact it under the national concern or national dimension doctrine, that is, a basis which coincides identically with the first submission made to us by counsel for Canada. Parliament did not purport to enact it under the extraordinary power which it possesses in time of national crisis. ${ }^{59}$

It is clear that Mr. Justice Beetz contemplated a distinction between admission of members' statements as an aid in construction and admission for the ascertainment of the Act's "constitutional pivot." Admitting, arguendo, the distinction to be valid, subjective legislative intent and its ascertainment by members' speeches become relevant in constitutional law. The statements reinforce the conclusion that the members thought that no emergency existed, and that adds weight, in Mr. Justice Beetz's view, to the conclusion of constitutional incompetence.

One might suppose that the Minister's statements are no more than another piece of objective evidence going to test the existence of an emergency-that is what those in a position to know thought about the existence of the supposed emergency. However, Mr. Justice Beetz does not use the statements in that way. Rather, he uses them to demonstrate the subjective intent of the legislature, the kind of purpose pursued and the source of constitutional power claimed relevant to that purpose. It may be that something of the rule as to inadmissibility of members' statements as an aid in construction survives, but the Reference re Anti-Inflation Act sweeps aside the rule for tests of constitutional validity.

Further, the distinction between members' statements as an aid in construction and as an aid in determining the "constitutional pivot" is too specious. The difference is imperceptible-it certainly does not warrant a per se exclusion rule in the former case and open admissibility in the latter. ${ }^{60}$ Any objections to the admissibility of members' statements could be met by a requirement that there be true ambiguity and by a caution going to weight of the evidence. On balance, therefore, evidence of members' statements, where relevant, ought to be admitted.

If this conclusion is sound, then the presumption of regularity takes on an added relevance where ambiguous legislative intent is crucial to the process of constitutional decision. The court should not hesitate to apply the presumption in order to require the building of an adequate evidentiary record helpful to resolving the disputed question. In this way, constitutional scrutiny of challenged legislation may be refined and more precise judicial answers may be given.

\section{Legislative Declarations of Facts}

Certain legislative powers require the existence of factual conditions before they can be constitutionally exercised. The most obvious example is

69 Id. at 472 (S.C.R.), 535 (D.L.R.).

${ }^{60}$ See text accompanying notes $42-45$, supra. 
Parliament's extraordinary power to invade provincial heads of jurisdiction during times of national crisis. A condition precedent to Parliament's lawful resort to the power is the existence, in fact, of an emergency. A second example would be provincial regulation of marketing congestion in certain commodities. Constitutionally competent regulation requires that the market, in fact, be provincial in scope; it could not be interprovincial or international. As a last example, regulation of local transport or communications undertakings by a province, or of interprovincial undertakings by Parliament, requires that organization of such undertakings, as a matter of fact, be substantially local or interprovincial, as the case may be. If the factual preconditions are not satisfied, the legislation must fall for constitutional defect. ${ }^{01}$

Where factual preconditions to the constitutionally valid exercise of legislative power exist, it would be unthinkable that the legislature would refrain from investigating the sufficiency of the necessary facts. The legislature has a formidable array of fact-finding machinery available for the purpose. It can summon experts before committees, procure special in-depth reports, or appoint royal commissions or other tribunals having wide investigatory powers under the Inquiries Acts. Judicial fact-finding tools pale beside the impressive resources of the legislature.

The legislatures do, of course, gather facts. It has become increasingly common for Canadian legislatures to declare in preambles to their acts the factual circumstances impelling them to legislative action or the constitutional facts supporting exercise of legislative power. In the Anti-Inflation Act, for example, the preamble contains the following:

WHEREAS the Parliament of Canada recognizes that inflation in Canada at current levels is contrary to the interests of all Canadians and that the containment and reduction of inflation has become a matter of serious national concern;

AND WHEREAS to accomplish such containment and reduction of inflation it is necessary to restrain profit margins, prices, dividends and compensation; ...02

Legislative facts were declared in Montreal By-Law 3926 (considered by the Supreme Court of Canada in A.G. Can. v. Dupond) as follows:

WHEREAS it is imperative to provide for the protection of citizens in the exercise of their liberties, safeguard public peace and prevent violence against persons and property;

WHEREAS violence, armed robberies and other criminal acts often accompany certain demonstrations;

WHEREAS it is in order to enact exceptional emergency measures for the protection of citizens and the maintenance of peace and public order;

WHEREAS it is in order to regulate the use of the public domain and safeguard the right of citizens to the peaceful enjoyment of the public domain of the City;

01 Examples are: Emergency: Fort Frances Pulp and Power Co. v. Man. Free Press Co., [1923] A.C. 695, [1923] 3 D.L.R. 629 (P.C.); Reference re Wartime Leasehold Regulations, [1950] S.C.R. 124, [1950] 2 D.L.R. 1; and Reference re Anti-Inflation Act, supra note 5; Marketing: Man. Egg and Poultry Ass'n, supra note 6; and Reference re Agricultural Products Marketing Act, supra note 4; Local and Interprovincial Undertakings: C.P.R. v. A.G.B.C., [1950] A. C. 122, [1950] 1 D.L.R. 721 (P.C.); A.G. Ont. v. Winner, [1954] A.C. 541, 13 W.W.R. 657, 71 C.R.T.C. 225 (P.C.); and Dionne, supra note 20.

62 S.C. $1974-75-76$, c. 75. 
and the ordinance passed by the Executive Committee of the City pursuant to section 5 of the By-Law stated:

CONSIDERING there are reasonable grounds to believe that the holding of assemblies, parades or gatherings on the public domain of the City would endanger the safety, peace or public order or might give rise to such danger;

CONSIDERING the exceptional situation prevailing in the City of Montreal and the need to take preventative measures to safeguard peace and public order. ${ }^{63}$

Legislative declarations of facts such as these raise nice questions concerning the presumption of regularity. How far towards irrebuttability does the presumption go? Does the presumption suggest that the facts as found by the legislature have not changed? Is there a presumption that the facts as found are adequate to support the challenged exercise of power?

This set of questions, which is specifically relevant to the presumption of regularity as applied to legislative declarations of facts, must be kept distinct from certain other situations. The difficulties do not concern whether or how far the court can presume the existence of facts required to support a challenged exercise of power. Conceptually, that is quite different. This last would be relevant to the existence of facts that the court or counsel says exist; the situation now considered relates to facts that the legislature says exist.

Two considerations make the instant problem especially probing: (1) the high respect and comity that exist between the legislative and judicial arms of government, and (2) the immensely superior fact-gathering capacity of the legislature as compared to that of the court.

\section{a) Rebuttable or Irrebuttable?}

The presumption of regularity as applied to legislative declarations of facts can mean only that the facts as declared, at least prima facie, are true. The comity that must exist between the legislature and the judiciary is a sufficient reason to apply the presumption in this way; the court presumes that the legislature presents an adequate picture resulting from a sufficient investigation. Any other attitude would tilt the court towards doubting in various degrees the good faith or diligence of the legislature: sound government cannot proceed on this basis.

Annexed to this is the relatively great capacity of the legislature to amass legislative and constitutional facts. This must be contrasted with the relative inexpertise of the courts in dealing with economic theories, specialist technical developments and the like. Courts are restricted to judicial notice of these matters and the actual facts as elaborated in the case. These may be a poor representation of reality. The issue, however, is not limited to two litigants, but also concerns the limits of governmental power. Additionally, it should be noted that legislative declarations of fact are often highly politically charged, as the Montreal anti-demonstration by-law illustrates. Thus, questions are raised as to the proper role for court and legislature. Professor Hogg has noted:

A legislature acts not merely on the basis of findings of fact, but upon its judg-

${ }^{63}$ [1978] 2 S.C.R. 770 at $782-84,84$ D.L.R. (3d) 420 at $429-30$. 
ment as to the public perceptions of a situation and its judgment as to the appropriate policy to meet the situation. These judgments are political.... It is not for the court to disturb political judgments....64

In view of all of this, it is reasonable to think that the presumption takes on added significance. Ultimately, it raises questions as to the conclusiveness of a decision. As a Michigan court aptly put it at the turn of the century: "Who shall decide the question, [of constitutional fact] and by what rule? Shall it be the legislature or the courts?"65 In the Michigan case, the court was clear to point out the "manifest absurdity" determine the constitutionality of a statute from the testimony developed in the case. That view has found favour with some American and Australian courts. Accordingly, there is a distinct line of authority that legislative declarations of facts are conclusive. These cases accept that the presumption of regularity, as applied to legislative declarations of facts, is irrebuttable. ${ }^{67}$

This line of authority is forcefully contradicted in the majority of American cases and finds little support in Australia. ${ }^{68}$ The point is made that the courts are the guardian of the constitution: that high responsibility cannot be forfeited by adopting an overly deferential posture in the fact-finding process

64 Proof of Facts in Constitutional Cases (1976), 26 U. Toronto L.J. 386 at 396-97.

65 People v. Smith, 108 Mich. 527 at 533, 66 N.W. 382 at 383-84 (S. Ct. Mich. 1896). The same question was put by an Oregon Court in Kadderly v. City of Portland, 44 Or. 118 at 147, 74 P. 710 at 720 (S. Ct. Ore. 1903): "But the vital question is, what tribunal is to determine whether a law does or does not fall under this classification? Are the judgment and findings of the legislative assembly conclusive, or are they subject to review by the courts"?

66 People v. Smith, id.

67 The American authorities are set out in four annotations: see 7 A.L.R. 519 at 522; 55 A.L.R. 779; 90 A.L.R. 328; 110 A.L.R. 1435 at 1438. The annotations deal only with the conclusiveness of legislative declarations of emergencies. A further annotation covering broader ground is available at $82 \mathrm{~L}$. Ed. 1244. In Australia, see the judgments of Dixon C.J. in Commonwealth Freighters Pty Ltd. v. Sneddon, supra note 10, at 292; Breen v. Sneddon (1961), 106 C.L.R. 406 at 411 (H.C.); and W. H. Blakeley \& Co. Pty v. The Commonwealth (1953), 87 C.L.R. 501 at 520 (H.C.).

68 See American Annotations, id., especially 82 L. Ed. 1244 at 1248-50. The clearest statement by an American court is in Chastleton Corp. v. Sinclair, 44 S. Ct. 405 at 406 (1924) per Holmes J.:

We repeat what was stated in Block v. Hirsh, 256 U.S. $135,154,41$ S. Ct. 458,65 L. Ed. 865,16 A.L.R. 165 , as to the respect due to a declaration of this kind by the Legislature so far as it relates to present facts. But even as to them a Court is not at liberty to shut its eyes to an obvious mistake, when the validity of the law depends upon the truth of what is declared.

In Australian Communist Party v. The Commonwealth (1951), 83 C.L.R. 1 at 222, the Australian High Court stated:

[I]t ... is the duty of the Court in every constitutional case to be satisfied of every fact the existence of which is necessary in law to provide a constitutional basis for the legislation.

Furthermore, in South Australia v. The Commonwealth (1942), 65 C.L.R. 373 at 432, that same Court was clear on the point:

The Court should treat this expression [legislative declaration of facts] of the view of Parliament with respect. In a doubtful case it might turn the scale, the presumption being in favour of the validity of Acts rather than of invalidity. But such a declaration cannot be regarded as conclusive. 
such as would sterilize the courts' capacity for independent judicial review. The Supreme Court of Canada in another context has been no less jealous to protect its responsibility to safeguard constitutional integrity. "A State ... is sovereign," said Dickson J., "and it is not for the Courts to pass upon the policy or wisdom of legislative will." ${ }^{\prime 69} \mathrm{He}$ continued:

As a broad statement of principle that is undoubtedly correct, but the general principle must yield to the requisites of the constitution in a federal state. By it the bounds of sovereignty are defined and supremacy circumscribed. The Courts will not question the wisdom of enactments which, by the terms of the Canadian Constitution are within the competence of the Legislatures, but it is the high duty of this Court to insure that the Legislatures do not transgress the limits of their constitutional mandate and engage in the illegal exercise of power. ${ }^{70}$

In the landmark constitutional fact case, Crowell v. Benson, the United States Supreme Court was equally precise:

It is rather a question of the appropriate maintenance of the federal judicial power in requiring the observance of constitutional restrictions.... In cases brought to enforce constitutional rights, the judicial power of the United States necessarily extends to the independent determination of all questions, both of fact and law, necessary to the performance of that supreme function. 71

The Canadian authorities have never ruled squarely on the issue of legislative declaration of facts. In the Board of Commerce Act Reference, the Privy Council was faced with counsel's argument that an emergency existed sufficient to trigger Parliament's extraordinary power. No legislative declaration in the Act itself reinforced that submission, but Viscount Haldane did say that the emergency principle "can be justified only after scrutiny sufficient to render it clear that the circumstances are abnormal."72 Further consideration was given in Fort Frances Pulp and Power Co. v. Manitoba Free Press $\mathrm{Co}^{73}$ Once again circumstances turned on counsel's submission of an emergency and not a legislative declaration. However, Viscount Haldane did make

09 Amax Potash v. Gov't of Sask., supra note 51, at 590 (S.C.R.), 10 (D.L.R.).

70 Id.

71285 U.S. 22 at 54-56, 52 S. Ct. 285 at 294-96 (1964). The case has generated an extremely lively controversy in the courts and academic journals very similar to the jurisdictional fact doctrine in administrative law. See, e.g., Dickinson, Crowell v. Benson: Judicial Review of Administrative Determinations of Questions of "Constitutional Fact" (1932), 80 U. Pa. L. Rev. 1055; and Larson, The Doctrine of "Constitutional Fact" (1941), 15 Temple L.Q. 185 at 208:

The real reasoning behind Crowell v. Benson is this: [I]t is the sole prerogative and duty of the Judiciary to keep Congress from exceeding its constitutional powers. If, therefore, Congress' action may in effect be carried over to situations beyond its powers just as effectively by a finding of fact ... the judicial prerogative of keeping Congress' action within bounds extends to examining those findings of fact....

Jaffe, Judicial Review: Constitutional and Jurisdictional Fact (1957), 70 Harv. L. Rev. 953. The problem has received further consideration by the U.S. Supreme Court: see Jones v. United States, 419 U.S. 907 at 910-11, 95 S. Ct. 190 at 192 (1974); and Uphaus v. Wyman, 360 U.S. 72 at 100, 79 S. Ct. 1040 at 1056 (1958).

72 Supra note 6, at 200 (A.C.), 519 (D.L.R.).

73 Supra note 61. 
it clear that the judiciary could interfere with governmental judgment that emergency measures were warranted:

But very clear evidence that the crisis had wholly passed away would be required to justify the judiciary ... in overruling the decision of the Government that exceptional measures were still requisite. ${ }^{74}$

A legislative declaration was contained in the National Emergency Transitional Powers Act, $1945^{75}$ considered by the Privy Council in Cooperative Committee on Japanese Canadians. ${ }^{70}$ The Act recited that an emergency continued following the surrender of Germany and Japan such as to require the Governor in Council to exercise certain transitional powers during the continuance of the emergency. Counsel attacked the continuance of the emergency on the facts, saying that no such emergency existed justifying the sweeping interference with the normal constitutional order. Lord Wright answered in this way:

The preamble to the Transitional Act states clearly the view of the Parliament of the Dominion as to the necessity of imposing the powers which were exercised. The argument under consideration invites their Lordships, on speculative grounds alone, to overrule either the considered decision of Parliament to confer the powers or the decision of the Governor in Council to exercise them. So to do would be contrary to the principles laid down in Fort Frances Pulp and Power Co. v. Manitoba Free Press and accepted by their Lordships earlier in this opinion.77 [Emphasis added.]

The clear implication is that the legislative declaration of emergency can be overcome by proper evidence, but not by speculation. In other words, though there is a presumption that the declaration is true, the presumption is rebuttable by evidence.78

The procedure adopted in the Reference re Anti-Inflation Act is worthy of special notice because that Act contained a declaration of legislative facts

$74 \mathrm{Id}$. at 706 (A.C.), 635 (D.L.R.). The statement was repeated almost verbatim by Lord Wright in Co-operative Comm. on Japanese Canadians, supra note 38, at 101.02 (A.C.), 585-86 (D.L.R.).

75 S.C. 1945 , c. 25.

76 Supra note 38.

77 Id. at 108 (A.C.), 592 (D.L.R.).

78 One discordant note in the authorities is struck in the Leasehold Reference, supra note 61 , at 126 (S.C.R.), 3 (D.L.R.). Chief Justice Rinfret required the Court to limit its inquiry "to the statements of fact contained in the order of reference." The statement is objectionable because it has the effect of making legislative declarations of facts in constitutional references irrebuttable. This means that the court would be abrogating its responsibility for independent constitutional review in cases turning on fact. The statement is highly dubitante. It cuts against all the authorities: see Hogg, supra note 64, at 391-92. An American author in Note, The Presentation of Facts Underlying the Constitutionality of Statutes (1936), 49 Harv. L. Rev. 631 at 634 notes that such a rule would allow "Congress ... to lift itself by its own boots straps, and such a rule would be unjust to the litigant already burdened with the presumption...." In Reference re AntiInflation Act, supra note 5 , the Court specifically considered a legislative declaration and directed that additional factual data be included in counsel's facta. A procedure was established for replying to the data. One is therefore driven to the conclusion that Chief Justice Rinfret's remark does not state Canadian law: see Strayer, supra note 37, at 178; and Hogg, op. cit., at 392. 
in the preamble. By calling for additional facts in counsel's briefs, the court certainly made it appear that the legislature's declaration invites scrutiny or, perhaps, fleshing out. Either way, however, it seems strange to think that a court, willing to involve itself in factual material in this way, will pretend that it did not notice that the legislature erred if, in the course of the court's inquiry, it appears that the facts are indeed otherwise than as declared. Mr. Justice Holmes' remark in Chastleton Corporation v. Sinclair seems especially pertinent in this context: "[A] court is not at liberty to shut its eyes to an obvious mistake, when the validity of the law depends upon the truth of what is declared."78 In view of the authorities and the courts' duty to protect the constitution by independent judicial review, one is entitled to conclude that Canadian courts will not shrink from reviewing legislative declarations of facts in a proper case; or, to state the point another way, the presumption of regularity, as applied to legislative declarations of facts, is rebuttable.

If this conclusion stands, section 2 of the War Measures Act comes into bold relief. That section provides:

\section{EVIDENCE OF WAR}

2. The issue of a proclamation by Her Majesty, or under the authority of the Governor in Council shall be conclusive evidence that war, invasion, or insurrection, real or apprehended, exists and has existed for any period of time therein stated, and of its continuance, until by the issue of a further proclamation it is declared that the war, invasion or insurrection no longer exists.80

The proclamation, referred to by section 6 , is the trigger for Parliament's assumption of emergency legislative powers.

The War Measures Act authorizes the Governor in Council to make sweeping orders and regulations relating to matters normally reserved exclusively to provincial jurisdiction. The Act allows for censorship (section 3a); regulation of intra-provincial transport (section 3d) and communications (section 3a); regulation of intra-provincial trade, production and manufacture (section $3 \mathrm{e}$ ); and regulation of property (section $3 \mathrm{f}$ ). The powers are to accrue only during war, invasion, or insurrection, real or apprehended. The constitutional theory behind this is that the crisis colours these matters with a national aspect in that the continuing life of the state itself is at stake. Parliament, therefore, acquires concurrent and ultimately paramount jurisdiction. ${ }^{81}$

The troubling feature about section 2 is that it purports to make a legislative declaration of emergency conclusive, or irrebuttable. Thus, Parliament's extraordinary power to invade provincial jurisdiction arises by executive fiat, and, according to the clear implication of section 2 , no court can interfere. At least one court has accepted that view. ${ }^{82}$

79 Supra note 68 , at 406.

80 R.S.C. 1970 , c. W-2.

81 The best explication of this theory is LeDain, Sir Lyman Duff and the Constitution (1974), 12 Osgoode Hall L.J. 261.

82 Gagnon v. The Queen, [1971] Que. C.A. 454, 47 D.L.R. (3d) 378, 14 C.R.N.S. 321. It is worthy of note that, to the author's knowledge, no western country goes so 
How can this be correct? It flies in the teeth of all the authorities and constitutional principles explained above. It is bad enough to think that the courts would relinquish their responsibility for constitutional review; it becomes particularly objectionable when the legislature itself attempts to interfere with and kill the judiciary's constitutional responsibilities. In any event, Parliament makes a legislative declaration of real or apprehended war or insurrection assisted by a presumption of regularity. Certainly, a declaration that extraordinary powers are called for to protect the nation is entitled to the highest respect, but section 2 denies the judiciary coordinate respect; it implies that circumstances have made constitutional review too austere for them. It attempts pro tanto a closing of the courts. In my submission, Parliament has no power to interfere with constitutional review in this-sweeping way. It is highly offensive to the constitutional position of the judiciary, to the principle of separation of powers, ${ }^{83}$ and to the theory of independent constitutional review which forms the most solid foundation upon which our federal system is grounded.

If this conclusion is correct, one of two possible results necessarily is implied: (1) as a matter of construction, section 2 does not exclude judicial review; or (2) section 2 itself is ultra vires.

Possibility (1) is problematic. If the declaration by the Governor in Council is not conclusive for the courts, for whom is it conclusive? It is not conclusive for administrative officials; they are in any case bound by Parliament's action unless or until the courts overturn such action. ${ }^{84}$ Certainly not for the executive who made the declaration. Thus it must be conclusive for the courts. That means that possibility (1) cannot be right. From this one must conclude that section 2 of the War Measures Act is an unconstitutional interference with the judiciary's responsibility to safeguard the Canadian constitution and ultra vires Parliament.

\section{b) Changing Facts}

If the constitutional exercise of legislative power must be supported by facts, it is not enough that the facts existed when the challenged act was passed. They, or some other sufficient factual conditions, must continue to exist so long as it is sought to exercise that particular power. If the facts cease to exist, lawful exercise of the power is at an end. ${ }^{85}$ Parliament's emergency power offers the readiest illustration. When the emergency in fact comes to

far; executive suspension of civil liberties and disruption of the normal constitutional balance of powers is generally reviewable. Very forward-looking emergency legislation was enacted by amendments to the German constitution, which the author described elsewhere: Magnet, Emergency Powers and Civil Liberties (Brief prepared on request of the Canadian Civil Liberties Association), February, 1979.

${ }^{83}$ See Liyanage v. The Queen, [1967] 1 A.C. 259 (P.C., Ceylon).

${ }^{84}$ Lessard v. Regem (1939), 67 B.R. 448 (Que. C.A.).

85 [A] statutory provision valid in its application under circumstances envisaged at the time of its enactment can no longer have a constitutional application to different circumstances under which it would, equally, not have been sustained had they existed at the time of its enactment....

per Laskin C.J.C. in Reference re Anti-Inflation Act, supra note 5, at 427 (S.C.R.), 499 (D.L.R.). 
an end, so does the constitutional use of extraordinary powers. ${ }^{86}$ Identical with this is the defence power possessed by the commonwealth government in Australia. The power expands and contracts with the facts. As explained by Dixon J. in Andrews v. Howell:

[U]nlike some other powers its [the defence power's] application depends upon facts, and as those facts change so may its actual operation as a power enabling the legislature to make a particular law.... The existence in character of hostilities, or a threat of hostilities, against the Commonwealth are facts which will determine the extent of the operation of the power. ${ }^{87}$

As explained above, the presumption of regularity as applied to the original legislative declaration means that the declaration prima facie is true; but does the presumption mean also that the facts are presumed to be true into the future? Is there a presumption that conditions as declared by the legislature have not changed?

There is a certain unreality about this conclusion for, if correct, it suggests that the legislature is capable of telling the future. This consideration struck one American court as improbable. In Chastleton Corporation v. Sinclair, after stating that the court must look to reality even in the teeth of a legislative declaration of fact, Mr. Justice Holmes continued: "And still more obviously so far as this declaration looks to the future it can no more than prophecy and is liable to be controlled by events." 88 If the legislature continues to exercise the power supported by the challenged facts, ought the court to presume that it does so constitutionally-that a sufficient factual foundation exists? Does this not imply that the facts as originally declared have not changed?

Such reasoning contains a considerable fallacy. The presumption of constitutionality as applied to legislative action implies only that the legislation is constitutional. As explained below, if validity of the legislation depends on facts, the evidentiary branch of the presumption creates a prima facie case that all necessary facts exist. ${ }^{80}$ That does not imply, however, that the facts declared by the legislature exist. The facts declared may be inadequate as a matter of law to support the challenged legislation. ${ }^{00}$ The

${ }^{86}$ Fort Frances Pulp and Power Co. v. Man. Free Press Co., supra note 61, at 706 (A.C.), 635 (D.L.R.). The position is the same in the United States-see Hamilton v. Kentucky Distilleries Co. (1919), 251 U.S. 146 at 162, 64 L. Ed. 194 at 202 (Ky., 1919); and Australia-see Australian Textiles Pty Ltd. v. The Commonwealth (1945), 71 C.L.R. 161 at 181 (H. Ct. of Aust.): "If a power applies to authorize measures only to meet facts, the measure cannot outlast the facts as an operative law."

87 (1941), 65 C.L.R. 255 at 278 (H. Ct. of Aust.).

88 Supra note 68, at 406.

89 [I] $\mathrm{f}$ any state of facts reasonably can be conceived that would sustain it [the challenged act], the existence of that state of facts at the time the law was enacted must be assumed. ...

Lindsley v. Natural Carbonic Gas Co., 220 U.S. 61 at 78, 31 S. Ct. 337 at 340 (1911). In light of recent authorities, it is now beyond doubt that that principle in Canada is the same. The authorities are discussed infra at IIC.

${ }^{00} \mathrm{Mr}$. Justice Beetz, in the Reference re Anti-Inflation Act, supra note 5, for example, took the view that the facts declared in the Act were insufficient to provide a constitutional foundation for the Act. 
presumption of regularity means that the facts as declared are true, but there is no reason why it should go further and imply that the facts declared have not changed.

The fallacy that engenders this erroneous conclusion turns upon employing the presumption of constitutionality in a different sense altogether than a presumption of regularity. It is employed as an evidentiary presumption of fact. However, the presumption of fact that conditions necessary to support the challenged Act exist does not imply that the facts declared have not changed. Those facts, as in the Reference re Anti-Inflation $A c t^{01}$ and Margarine Reference, ${ }^{82}$ may never have been adequate to support the Act. The evidentiary branch of the presumption never would have suggested them to the Court.

The distinction between the two aspects of the presumption of constitutionality is fine, but real and important. It determines what it is that the litigant attacking legislation must overcome. If he must overcome a presumption of regularity as applied to a declaration of facts, he has a considerable hurdle. He must negative, in that instance, what the legislature has expressly affirmed. If, however, he must overcome the evidentiary presumption that sufficient facts exist to support the challenged exercise of power, his burden is lightened. He has the onus in that event only to build a record of evidence. He has no facts specifically to deny, nor must he show that the legislature was in error. The evidentiary presumption relieves the government from proving facts supporting its legislation. It casts an onus on the attacker to establish a sufficient evidentiary record to support his allegation of ultra vires.

Appreciation of the distinction between a presumption of regularity and an evidentiary presumption throws considerable light on statements made by the Privy Council in Fort Frances Pulp and Power Co. v. Manitoba Free Press $^{93}$ and Co-operative Committee on Japanese Canadians. ${ }^{04}$ In the former case, Viscount Haldane noted:

The other point which arises is whether such exceptional necessity as must be taken to have existed when the war broke out, and almost the necessity for some period subsequent to its outbreak, continued.... [V]ery clear evidence that the crisis had wholly passed away would be required to justify the judiciary ... in overruling the decision of the Government that exceptional measures were still required.95

The crucial point to notice is that the "clear evidence" referred to is not evidence to rebut any legislative declaration of fact; ${ }^{90}$ it is evidence as to the

\section{Id.}

92 Can. Fed'n. of Agric. v. A.G. Que., [1951] A.C. 179, [1950] 4 D.L.R. 689 (P.C.).

93 Supra note 61.

94 Supra note 38.

95 Supra note 61, at 705-06 (A.C.), 635 (D.L.R.), repeated by Lord Wright in the Japanese Canadians case, id. at 101-02 (A.C.), 585-86 (D.L.R.); and by Mr. Justice Ritchie in Reference re Anti-Inflation Act, supra note 5, at 439 (S.C.R.), 509 (D.L.R.).

96 There was no legislative declaration of fact in Fort Frances. The point takes on added subtlety in Japanese Canadians, for a legislative declaration is considered in that case, but the logic of the point survives, especially in view of Lord Wright's almost exact repetition of the legal principle enunciated by Viscount Haldane in Fort Frances. 
existence in reality of the crisis situation necessary to justify continued use of Parliament's extraordinary power. The effect on the attacker is profound. He has no statement by Parliament to negate. What he must do is establish such an evidentiary record as will demonstrate that no crisis exists at the moment of constitutional attack capable of supporting Parliament's use of extraordinary power. If he fails to establish a sufficient evidentiary record, the court presumes the existence of all facts necessary to support the challenged exercise of legislative power.

\section{c) Rational Basis}

The rational basis doctrine in constitutional law bristles with ambiguities. It originates in the United States in the evidentiary branch of the presumption of constitutionality. The first and fundamental meaning of the doctrine is relevant to the standard of proof required to sustain a constitutional attack based on facts. The government supporting legislation need only show, by the presumption of constitutionality or otherwise, that there is a rational basis upon which to conclude that facts necessary to support its act exist. As explained in Borden's Farm Products Co. v. Baldwin:

Where the legislative classification is suitably challenged, and a rational basis therefore is predicated upon particular economic facts of a given trade or industry, which are outside the sphere of judicial notice, such facts are properly the subject of evidence and of findings. 97

Even in American law, the words "rational basis" mean different things to different persons. A second and third meaning grow out of language used in Mr. Brandeis' famous brief in Muller v. Oregon:

The question is merely whether, as has been stated, you can see that the legislators had no ground on which they could, as reasonable men, deem this legislation appropriate to abolish or mitigate the evils believed to exist. ...98

The point here is that the legislative scheme rationally must be related to a constitutionally valid purpose. ${ }^{99}$ This aspect has been extensively used in Australia. ${ }^{100}$ As explained by Professor Lane:

97293 U.S. 194 at 194, 55 S. Ct. 187 at 187 (1934).

98208 U.S. 412, 28 S. Ct. 324 (1908) as cited in Freund, On Understanding the Supreme Court (Westport, Connecticut: Greenwood Press, 1977) at 89.

99 As explained by Frankfurter, Hours of Labor and Realism in Constitutional Law (1915-16), 29 Harv. L. Rev. 353 at 365:

[T]he Muller case is 'epoch-making' ... because of the authoritative recognition by the Supreme Court that the way in which Mr. Brandeis presented the case-the support of legislation by an array of facts which established the reasonableness of the legislative action, however it may be with its wisdom-laid down a new technique for counsel charged with the responsibility of arguing such constitutional questions....

100 Australian Communist Party v. The Commonwealth, supra note 68, at 140 and 153; Australian Textiles Pty Ltd. v. The Commonwealth, supra note 86, at 183 per McTiernan J.:

It is enough for present purposes to hold that the payment of the rates may reduce the disparities. The hypothesis that the reduction of the disparities may help forward the industries and in some circumstances aid their survival is a reasonable one. I think that a connection may be shown to exist between the payment of the rates prescribed by the Regulation and the purpose of re-establishing the members of the forces in civil life. 
In other cases, facts would be relevant to establish that the means chosen by Parliament are inappropriate to secure a concededly legitimate end. Thus, a State law which prescribes a length and height for vehicles appears to be a safety regulation and prima facie consistent with s. 92; the defined length and/or height, however, may not be in fact an appropriate means to secure safety on highways.101

The third branch of the doctrine refers to the unreasonableness of a statute which, although connected with a constitutional power, produces intolerable interference with other constitutional protections (such as due process).102 This branch of the doctrine has been explained as follows:

The inquiry into the reasonableness of an act may then be described as a single one, in which the court must evaluate the relative weights of the beneficial consequences which would follow from upholding the statute, and the price which must be paid for them in the form of the resulting deprivation of liberty or property.... Four elements in the analysis of the reasonableness of an act, though closely interrelated, may be roughly distinguished: the conditions existing prior to the legislation, the effectiveness of the new rule to improve them, the deprivation resulting from the new rule, and the possibility of achieving the same benefits at a lower price. 103

This aspect of the doctrine proves appealing in cases where Bill of Rights issues are raised in American courts.

In Canada, the rational basis doctrine was introduced as a tool for constitutional scrutiny in Reference re Anti-Inflation Act. $^{104}$ However, it is extremely important to notice that Chief Justice Laskin and Mr. Justice Beetz used the concept in two different senses. Mr. Justice Laskin used the rational basis test in the second sense explained above-the legislature had to show only that the challenged act was rationally connected to a constitutionally valid purpose:

[T]his Court would be unjustified in concluding, on the submissions in this case and on all the material put before it, that the Parliament of Canada did not have a rational basis for regarding the Anti-Inflation Act as a measure which, in its judgment, was temporarily necessary to meet a situation of economic crisis imperilling the well-being of the people of Canada as a whole....106

Mr. Justice Beetz, however, explained the doctrine in the first sense detailed above; there must be a rational basis to conclude, as a matter of fact, that conditions justified resort to the challenged power:

We were provided with a wealth of extrinsic material the consideration of which, it was expected, would enable us to make a finding of fact as to whether or not inflation had reached a level which justified Parliament's reliance on its extraordinary power or as to whether or not there was a rational basis for Parliament to judge that it could rely upon that power.100

101 Facts in Constitutional Law, supra note 10, at 116.

102 See, e.g., Barnett, External Evidence of the Constitutionality of Statutes (1924), 58 Am. L. Rev. 88 at 94.

103 Note, The Consideration of Facts in "Due Process" Cases (1930), 30 Col. L. Rev. 360 at 362 .

104 Supra note 5.

105 Id. at 474 (S.C.R.), 498 (D.L.R.).

108 Id. at 470 (S.C.R.), 534 (D.L.R.). 
A similar lack of accord is apparent among academic commentators who have attempted to explicate the doctrine. ${ }^{107}$

Putting to one side for the moment the different meanings clustered together in the rational basis concept, is there any sense in which it can be relevant to the presumption of regularity as applied to legislative declarations of facts? Logically, the only way this could be so is if the presumption means that the facts as declared by the legislature are adequate to support the challenged exercise of power.

The instant point involves precise distinctions; it is helpful to keep them plainly in view. The point does not concern whether facts may be presumed to support a challenged exercise of power, nor does it concern whether facts declared by the legislature are presumed true. The question now considered is whether the court will presume that because the legislature has declared the existence of certain facts, those facts are presumed to afford a sufficient factual basis to support a challenged exercise of constitutional power.

The Canadian authorities negative this proposition conclusively. ${ }^{108}$ As a matter of logic, it is hard to see that the presumption of regularity can be applied in this way. It is the responsibility of the courts to state and apply constitutional principle. It is hard to see how a declaration of fact by the legislature can influence that responsibility. Factual conditions, real or presumed, have no bearing on statement of constitutional principles. Because the legislature declares, for example, that inflation "has become a matter of serious national concern" as it did in the Anti-Inflation Act, it does not follow that the truth of that declaration gives the legislature a constitutional right to enact curative measures. As Mr. Justice Beetz replied to this contention: "The words 'a matter of serious national concern' have been emphasized. I remain unimpressed." 109

The presumption that all facts necessary to support a challenged exercise of power exist, the presumption that certain declared facts are true, or lightening the standard of proof for certain facts-all of which are separate aspects of the presumption of constitutionality doctrine-are very different things than lightening the burden of constitutional demonstration as a matter of law. The first set of principles consists of evidentiary matters; the second is the inductive statement of constitutional principle and the deductive application of constitutional principle in the circumstances. The latter is the high res-

107 Professor Buglass, in The Use of Extrinsic Evidence and the Anti-Inflation Act Reference (1977), 9 Ottawa L. Rev. 183 at 190, thinks that the doctrine (as used by Laskin J.) relates to both factual findings and connection to a constitutionally valid purpose. Professor Hogg, in Proof of Facts in Constitutional Cases, supra note 64, at 396-97, explains the doctrine as a standard of proof relating to the evidentiary branch of the presumption. The late Professor Abel (who reviews some of the American authorities), in The Anti-Inflation Judgment: Right Answer to the Wrong Question? (1976), 26 U. Toronto L.J. 409 at $418-19$, explains the doctrine as requiring a rational connection between the act and constitutionally legitimate purposes.

108 In Can. Fed'n. of Agric. v. A.G. Que., supra note 92, the Privy Council used facts declared in the order of reference as a lever to invalidate the challenged act.

${ }^{109}$ Supra note 5, at 466 (S.C.R.), 531 (D.L.R.). 
ponsibility of our courts. It is a matter of legal principle, not of evidence. Accordingly, the rational basis test-whatever be its precise meaning-has no application to the presumption of regularity.

\section{B. Canon of Construction}

The commentators jump seven different ways when explaining the precise nature of the presumption of constitutionality, ${ }^{110}$ but all are agreed on one point: at the minimum, the presumption creates a rule of construction. Mr. Justice Strong has asserted:

It is our very duty to make every possible presumption in favour of such legislative acts, and to endeavour to discover a construction of the British North America Act which would enable us to attribute an impeached statute to a due exercise of constitutional authority. 111

Mr. Justice Cartwright was no less precise in McKay v. The Queen:

[I] $f$ words in a statute are fairly susceptible of two constructions of which one will result in the statute being intra vires and the other will have the contrary result, the former is to be adopted. ${ }^{112}$

All are agreed that the presumption of constitutionality creates a canon of construction; but, as demonstrated by these two holdings, there is no agreement on how that rule should be applied. Is it a rule of construction applicable to the B.N.A. Act, as Mr. Justice Strong held, or is it a rule of construction relevant to the challenged act, as held by Mr. Justice Cartwright, or is it both?

\section{Construction of the B.N.A. Act}

A canon of construction that strains the B.N.A. Act in the direction of a challenged statute is a ticklish proposition. It certainly cuts against the established momentum gathered by the "watertight compartments" theory113 in that it makes construction of the B.N.A. Act so flexible as to allow all but the most offensive enactments. To facilitate judicial administration of this

110 Most doubt that it exists: for example, Professor Hogg: "It cannot be said that a presumption of constitutionality has been explicitly recognized in Canada...." in Constitutional Law of Canada, supra note 52, at 88; in Laskin's Canadian Constitutional Law (4th ed. Toronto: Carswell, 1973) at 89: "[T] tutionality ... is no more than a canon of construction"; and Abel, The Anti-Inflation Judgment: Right Answer to the Wrong Question?, supra note 107, at 417: "[A] presumption of constitutionality ... perhaps has not been naturalized in Canada." Also relevant is Professor Laskin's comment in "Peace, Order and Good Government ReExamined" in Lederman, The Courts and the Canadian Constitution (Toronto: McClelland \& Stewart, 1971) 66 at 72, which suggests that the presumption does not apply to exercise of Parliament's extraordinary power:

The Board is now unwilling to make any assumption in favour of the validity of

Dominion legislation for the peace, order and good government of Canada....

111 Severn v. The Queen, [1879] 2 S.C.R. 70 at 103, 1 Cart. 414 at 447; repeated in R. v. Snyder (1967), 61 W.W.R. 112 at 118 (Alta. S. Ct.).

112 [1965] S.C.R. 798 at 804, 53 D.L.R. (2d) 532 at 537.

113 "[W]hile the ship of state now sails on larger ventures and into foreign waters she still retains the watertight compartments which are an essential part of her original structure": A.G. Can. v. A.G. Ont., [1937] A.C. 326 at 354, [1937] 1 D.L.R. 673 at 684 (P.C.) [hereinafter Labour Conventions case]. 
construction rule, it would be necessary to free the courts from "original intent" approaches to constitutional interpretation. Only the elastic language of the B.N.A. Act then would limit judicial inventiveness in construction. This implies exclusion of archival material pertaining to the making of the B.N.A. Act. Additionally, stare decisis would have to be attenuated in constitutional litigation. That doctrine, as the constitution ages, constricts the constitution's meaning; freedom in constitutional interpretation withers over time under its influence.

Comparative study of constitutional law reveals that different jurisdictions operate under different rules as to the admission of constitutional archival material. Many of the American states admit it freely. The draftsmen of the new Florida constitution, for example, have compiled an extensive record with the process of constitutional interpretation specifically in view.114 The Illinois constitution, which came into force in 1970 , had been considered by 1975 in thirty-three cases. Twenty-seven of these resorted to the constitutional record as a primary aid in construction. ${ }^{115}$

The thrust behind these examples cuts down the power of the courts. The constitutional review jurisdiction is limited to the specific inspiration of the constituting documents; the constitution's meaning can neither change nor grow. However, it necessarily follows from this approach that judicial power to strain construction of the constituting document towards supporting the validity of challenged acts is attenuated. The construction rule flowing from the presumption of constitutionality pales in significance before the paramount constitutional record.

The Canadian constitutional position differs. Shortly after Confederation, Canadian Supreme Court judges were prepared to look at "external aids . . . surrounding circumstances and the history of the subject matter ...,"116 in construing the B.N.A. Act. However, the Privy Council early on refused to admit archival evidence. During argument in Maher v. Town of Portland, counsel began his answer to a question as follows: "When the Earl of Carnarvon introduced the B.N.A. Bill-." He was stopped. James L.J. replied icily: "We shall not be influenced by anything then said."117 In $A . G$. Ont. v.

114 See generally Levinson, Interpreting State Constitutions by Resort to the Record (1978), 6 Fla. State U. L. Rev. 567.

115 Lousin, Constitutional Intent: The Illinois Supreme Court's Use of the Record in Interpreting the 1970 Constitution (1975), 8 John Marshall J. of Prac. and Proc. 189 at 190. See generally Antieau, Constitutional Construction: $A$ Guide to the Principles and their Application (1975-76), 51 Notre Dame Law. 358; Wofford, The Blinding Light: The Uses of History in Constitutional Interpretation (1963-64), 31 U. Chi. L. Rev. 502; Dewey, James Madison Helps Clio Interpret the Constitution (1971), 15 Am. J. of Legal Hist. 38; and Annotation, Resort to Constitutional or Legislative Debates, Committee Reports, Journals, Etc., as Aid in Construction of Constitution or Statute, supra note 53.

116 St. Catharines Milling and Lumber Co. v. The Queen (1887), 13 S.C.R. 577 at 606 per Strong J. (dissenting). See also In Re Prohibitory Liquor Laws (1895), 24 S.C.R. 170 at 231, 5 Cart. 323 at 346.

117 Wheeler, Confederation Law of Canada (London: Eyre and Spottiswoode, 1896) at 362 . 
Winner, ${ }^{118}$ counsel proposed to refer to the London Resolutions which preceded passage of the B.N.A. Act. Their Lordships ruled the material inadmissible.

The general rule as to non-admissibility was stated by Professor Kennedy in 1937:

[A] complete examination of all the cases in all the courts in which have arisen problems connected with the British North America Act discloses that, in the overwhelming majority of them, the ratio decidendi depended on reasoning entirely divorced from external sources or references, to which we cannot allow even a secure position as persuasive authorities. 110

These precedents have to be read against the recent Reference re The Senate. In this unanimous judgment the Supreme Court of Canada referred directly to the Quebec Conference of 1864 which preceded enactment of The British North America Act, 1867. The Court held:

It is, we think, proper to consider the historical background which led to the provision which was made in the Act for the creation of the Senate as part of the apparatus for the enactment of federal legislation. 120

The Court then went on to consider the pre-Confederation conferences, and the speeches of Macdonald and Brown were noted. A conclusion was drawn as to the primary purpose for the creation of the Senate.

What synthesis can be made of these conflicting authorities? The position would appear to be this: Original intent theories of constitutional interpretation gather little strength from the constitutional record in Canada. There are two reasons for this: (1) There is little useful material relevant to the meaning of the B.N.A. Act; and (2) original intent approaches to constitutional interpretation are foreign to our traditions and constitutional history. In matters of construction, Canadian judges are freer than are many of their

118 Supra note 61, at 554 (A.C.), 661 (W.W.R.).

118 The British North America Act: Past and Future (1937), 15 Can. B. Rev. 393 at 394. The proposition was cited approvingly by MacDonald in an excellent and influential article, Constitutional Interpretation and Extrinsic Evidence, supra note 46, at 81. Professor Laskin (as he then was) explained the rule as a phenomenon partly associated with the kind of archival materials available in Canada [in Canadian Constitutional Law (3d ed. Toronto: Carswell, 1969) at 154]:

The Confederation Debates, 1865 , recording the deliberations of the members of the Legislature of the then Province of Canada on the Quebec Resolutions contain by and large merely generalized assessments of the division of legislative authority. Pope's Confederation Documents (1895) add iittle to our understanding of the scope and relationship of the heads of power distributed by the B.N.A. Act. There is no verbatim record of debate at either the Quebec Conference of 1864 or the London Conference of 1866 but only the conclusions reached in the resolutions and successive drafts of the proposed confederating statute.... The Courts were left largely with their tools of logic and precedent, with contemporary or past legislative comparisons, with such rules of construction as they chose to apply, with dictionaries and other works of reference and, above all, with their own particular philosophies of federalism in general and Canadian federalism in particular.

This note is not carried forward in the 4th revised edition, an omission, in the author's view, to be regretted.

120 (1979), 30 N.R. 271 at 282 (S.C.C.). 
American brethren to review and expand the Constitution's meaning within the constitutional review jurisdiction. ${ }^{121}$ However, in the limited situations where significant archival material exists, the court will consider that archival material in order to determine the original content of the B.N.A. Act. From that original position, the court will extend the meaning of the constitution to conform to current conditions. ${ }^{122}$

Nor will the courts allow the generality of the B.N.A. Act to be narrowed by any specific interpretation that Parliament or a provincial legislature seeks to attach by legislation. In a federal Act ${ }^{123}$ consolidating certain insurance statutes, a declaration was made to the effect that each of the provinces retained exclusive legislative control over insurance companies incorporated by it. The Privy Council was prepared to utilize that declaration —at odds with Dominion counsel's submissions- to add weight to the Board's rejection of those submissions. However, Sir Montague Smith was clear in stating that the declaration by Parliament was not, and could not be, controlling:

The declarations of the dominion parliament are not, of course, conclusive upon the construction of the British North America Act; but when the proper construction of the language used in that Act to define the distribution of legislative

121 There are some discordant notes to be sounded along with this conclusion: see In re The Regulation and Control of Aeronautics in Canada, [1932] A.C. 54 at 70, [1931] 3 W.W.R. 625 at 632 (P.C.):

Inasmuch as the [B.N.A.Act] embodies a compromise under which, the original Provinces agreed to federate, it is important to keep in mind that the presentation of the rights of minorities was a condition on which such minorities entered into the federation and the foundation upon which the whole structure was subsequently erected. The process of interpretation as the years go on ought not to be allowed to dim or to whittle down the provisions of the original contract upon which the federation was founded, nor is it legitimate that any judicial construction of the provisions of ss. 91 and 92 should impose a new and different contract upon the federating bodies.

To the same effect are the remarks of Morin, A Constitutional Court for Canada (1965), 43 Can. B. Rev. 545 at 551:

[T] here should be limits to the discretion of constitutional judges.... The essential raison d'être of federalism, in a binational country like Canada, should be to protect the values and rights of the constituent groups and their autonomy, even against the will of the majority group. If you introduce into the Constitution a "principle of growth," such as that which has been developed in the United States, and the techniques of interpretation which are corollaries of this principle, you can have no feeling of security, at least in French Canada.

These remarks sound strange against the overwhelming weight of the Canadian authorities, especially the recent authorities. By the Canadian cases, the B.N.A. Act is viewed as a document of "evolving meaning, not limited to its original inspiration": CIGOL v. Gov't of Sask., supra note 5, at 583 (S.C.R.), 475 (D.L.R.); "a living tree capable of growth and expansion within its natural limits": Edwards v. A.G. Can., [1930] A.C. 124 at 136, [1929] 3 W.W.R. 479 at 489; and "a resilient instrument capable of adaptation to changing circumstances": Reference re Anti-Inflation Act, supra note 5, at 412 (S.C.R), 485 (D.L.R.). See also A.G. Que. v. Blaikie (1979), 30 N.R. 225 (S.C.C.). For further authorities, see Magnet, supra note 56, at 498 n. 102.

122 A.G. Que. v. Blaikie, id.

12340 Vict., c. 42 , s. 28. 
powers is doubtful, the interpretation put upon it by the dominion parliament in its actual legislation may properly be considered.124

Furthermore, stare decisis never has played the paramount role in Canadian constitutional law that it has in private law or in the constitutional law of certain other jurisdictions. The Privy Council, unlike the House of Lords, never considered itself bound by its own decisions. ${ }^{125}$ In Canadian constitutional matters, this point was underlined, and the relevance of the doctrine especially downplayed. Thus, in the Aeronautics Reference, their Lordships said:

Great care must therefore be taken to consider each decision in the light of the circumstances of the case in view of which it was pronounced.... [For, u]seful as decided cases are, it is always advisable to get back to the words of the Act itself and to remember the object with which it was passed.120

The Supreme Court has always threatened to overrule itself or the Privy Council in constitutional matters. Recently, it has done both. ${ }^{127}$

The truncated significance given to stare decisis dims the light on precedent and spotlights the words of the B.N.A. Act itself. Those words are extremely general and elastic; the courts are astute to protect that elasticity, "as far as possible to prevent too rigid declarations of the courts from interfering with such elasticity as is given in the written constitution."128

Constitutional interpretation in Canada is not at all unlike the interpretative process relevant to civil codes; it gathers strength from the flourishing example of civilian interpretation in the Province of Quebec. The generality of words exhibited by the B.N.A. Act, like the Code Civil, remains undiminished by decisions in actual cases; the breadth of legal statement invites doctrinal enrichment and expansion. The presumption of constitutionality, applied as a canon of construction relevant to the B.N.A. Act, is a tool capable of aiding the flexibility of constitutional interpretation. It heightens the sensitivity of our courts to the expanding meaning of the B.N.A. Act; a spotlight is thrown on the curial duty to control and further that movement. The presumption of constitutionality, so conceived, is a great source of richness and strength for our constitutional law.

\section{Construction of the Challenged Act}

It is well established in Canadian jurisprudence that if a challenged act is susceptible of two constructions, one of which is defective, it will be construed so as to render it intra vires. Counsel regularly makes two submissions:

124 Citizens Ins. Co. v. Parsons, supra note 13, at 116 (App. Cas.), 281 (Cart.).

125 Tooth v. Power, [1891] A.C. 284 (P.C., N.S.W.).

126 In re The Regulation and Control of Aeronautics in Canada, supra note 121, at 70 (A.C.), 632 (W.W.R.).

127 McNamara Construction (Western) Ltd. v. The Queen, [1977] 2 S.C.R. 654, 75 D.L.R. (3d) 273 (prior Supreme Court of Canada judgment overruled); Reference re Agricultural Products Marketing Act, supra note 4 (prior Privy Council judgment overruled).

128 Proprietary Articles Trade Ass'n v. A.G. Can., [1931] A.C. 310 at 317, [1931] 1 W.W.R. 552 at 554 (P.C.). 
(1) the act is ultra vires and (2) as a matter of construction the challenged act cannot apply to the attacker's circumstances. The rule flows from the presumption of constitutionality, as Fauteux $\mathbf{J}$. explained:

There is a presumptia juris as to the existence of the bona fide intention of a legislative body to confine itself to its own sphere and a presumption of similar nature that general words in a statute are not intended to extend its operation beyond the territorial authority of the Legislature. 129

Academic commentators term the phenomenon "reading down"; the wide reach of the statute is narrowed so as to avoid offending constitutional prohibitions. ${ }^{130}$ Similarly, the courts will not invalidate a wide grant of power because it might lead to abuse; legislative or administrative misconduct is never assumed. ${ }^{131}$ More than speculation or conjecture is needed to sustain a conclusion of constitutional incompetence. ${ }^{132}$ As Mr. Justice Ritchie explained in McNeil v. Nova Scotia Board of Censors:

It is true that no limitations on the authority of the Board are spelled out in the Act and that it might be inferred that it could possibly effect some of the rights listed by Macdonald, J.A., but having regard to the presumption of constitutional validity to which $I$ have already referred, it appears to me that this does not afford justification for concluding that the purpose of the Act was directed to the infringement of one or more of those rights. With the greatest respect, this conclusion appears to me to involve speculation as to the intention of the Legislature and the placing of a construction on the statute which is nowhere made manifest by the language employed in enacting it. ${ }^{133}$

All of this is settled law.

\section{Evidentiary Presumption of Fact}

\section{The Presumption in Canada: New Directions}

Twelve years ago Professor McWhinney drew attention to the significance of "more sophisticated rules and practice as to representation and recognition of governmental parties in constitutional cases ...." Such rules and practice, he said, "have gone a long way ... to purge Canadian constitutional jurisprudence of this purely unreal conflict of governmental

129 Reference re Farm Products Marketing Act, supra note 41, at 255 (S.C.R.), 311 (D.L.R.). See also Bank of Toronto v. Lambe (1887), 12 App. Cas. 575 (P.C.); Valin v. Langlois (1879), 5 App. Cas. 115 (P.C.); Citizens Ins. Co. v. Parsons, supra note 13; Hodge v. The Queen (1883), 9 App. Cas. 117 (P.C.); A.G. Ont. v. A.G. Can., [1894] A.C. 189,5 Cart. 266 (P.C.) (argument of A.G. Ont.); and A.G. Ont. v. Reciprocal Insurers Co., supra note 34. The most recent statement of the doctrine at this writing is Stubbe v. P. F. Collier \& Son Ltd. (1977), 74 D.L.R. (3d) 605 at 642, [1977] 3 W.W.R. 493 at 539 (B.C.S.C.). The doctrine exists as well in Australia: see generally Lane, The Australian Federal System (Sydney: Law Book Co., 1972) at 878. See also La Société Radio-Canada v. Cordeau, unreported, June 28, 1979, at 25 (S.C.C.).

130 Lane, id. at 878; Hogg, supra note 110, at 88: "A more limited presumption of constitutionality has been explicitly recognized in Canada as a canon of construction which forms the basis of the 'reading down' doctrine...."

131 Bank of Toronto v. Lambe, supra note 129, at 587.

132 CIGOL v. Gov't of Sask., supra note 5, per Dickson J., dissenting.

133 (1978), 19 N.R. 570 at 606-07, 25 N.S.R. (2d) 128 at 164-65 (S.C.C.). 
sovereignties in the abstract,"134 but he thought that there were still problems. Canadian constitutional law remained "un-fact-oriented." Although progress had been made, effective fact-finding techniques still awaited acceptance by the Supreme Court. ${ }^{135}$

Professor McWhinney's observation was acute and timely. His complaint as to "un-fact-orientedness" did not fall on deaf ears; it was picked up and developed by others. ${ }^{136}$ Then, in 1971, Mr. Justice Laskin, in the Manitoba Egg Reference, castigated the whole course of Canadian constitutional decision and its abstractness. His comments could not have been more severe, or more precisely on point. They signalled a decisive change in the attitude of the Supreme Court. He said:

The utility of the Reference as a vehicle for determining whether actual or proposed legislation is competent under the allocations of power made by The B.N.A. $A c t$ is seriously affected in the present case because there is no factual underpinning for the issues that are raised by the Order of Reference. Marketing data to illuminate those issues might have been set out in the Order itself (as was done, for example, in the Margarine Reference [Reference re Validity of s. 5(a) of Dairy Industry Act (Margarine Case), [1949] I D.L.R. 433, [1949] S.C.R. 1] or in an agreed statement of facts, or, indeed, might have been offered to the court to indicate the circumstances which prompted the questions addressed to it.

As it is, I know nothing of the nature of the market for eggs in Manitoba or outside of it, nothing of the uses to which the production is put, nothing of the numbers of producers in Manitoba, nothing of any problems that may have been created in relation to quality, price or otherwise by the entry of out-of-province eggs....

...

A knowledge of the market in Manitoba, the extent to which it is supplied by Manitoba producers, and of the competition among them as it is reflected in supply, quality and price, would be of assistance in determining the application of the proposed legislative scheme. Thus, if out-of-province eggs were, to put an example, insignificant in the Manitoba market, this would be a factor bearing on a construction of the scheme as operative only in respect of Manitoba producers, retailers and consumers in production, distribution and consumption in Manitoba. Conversely, if such eggs were significant in the Manitoba market, the legislative scheme, not being expressly confined to production, distribution and consumption in Manitoba, could properly be regarded as directed to the out-of-province eggs. In this respect, the issue would be one of its validity or invalidity, and not one of construing it to be applicable only to the distribution and consumption within the Province of eggs produced in the Province. ${ }^{137}$

A means to ameliorate the deficiency lay close at hand-the presumption of constitutionality. However no court applied the presumption as a presumption of fact; commentators continued to doubt that the presumption had any relation to the factual record. ${ }^{138}$ Instead, the commentators concentrated

184 McWhinney, The New Pluralistic Federalism in Canada (1967), 2 R.J.T. 139 at 143.

$1351 d$.

${ }^{136}$ See Strayer, supra note 37 , at 155 : "The suggestion is frequently made that Canadian constitutional adjudication has suffered from a lack of the factual element." ${ }^{137}$ A.G. Man. v. Man. Egg and Poultry Ass'n, supra note 6, at 704-05 (S.C.R.), 181-82 (D.L.R.).

138 See note 110 , supra. 
their major lamentations on the lack of "Brandeis brief advocacy" in Canadian constitutional litigation.

This persistent failure to perceive the relationship between the presumption of constitutionality, applied as an evidentiary presumption of fact, and the "abstractness" of Canadian constitutional decision occurred notwithstanding (or perhaps in spite of) the flourishing American example of using the presumption as a presumption of fact as early as the nineteenth century. In Lindsley v. Natural Carbonic Gas Company, Mr. Justice Van Devanter stated:

[I]f any state of facts reasonably can be conceived that would sustain it [the challenged Actl, the existence of that state of facts at the time the law was enacted must be assumed. ${ }^{138}$

Mr. Justice Van Devanter's formulation provided an influential lead. It was repeated by Chief Justice Hughes in Borden's Farm Products Co. v. Baldwin $^{140}$ and developed by Mr. Justice Brandeis in Pacific State Box \& Basket Co. v. White. ${ }^{141}$ In the latter case, Mr. Justice Brandeis pointed out that the presumption applied not only to all facts needed to invoke a constitutionally valid exercise of power in the abstract, but that it attached as well to specific applications of legislation to concrete facts and circumstances. He said:

[W] here the regulation is within the scope of authority legally delegated, the presumption of the existence of facts justifying its specific exercise attaches alike to statutes, to municipal ordinances, and to orders of administrative bodies. ${ }^{142}$

That is only one line of United States authority. There are two further senses in which the evidentiary branch of the presumption is applied in America. In the second sense, the presumption indicates the standard of proof that the attacker of legislation has to meet. He must present proof beyond all reasonable doubt, as a matter of fact, that the legislation is un-

139 Supra note 89, at 78 (U.S.), 340 (S. Ct.).

140 Supra note 97, at 209 (U.S.), 192 (S. Ct.) :

When the classification made by the legislature is called in question, if any state of facts reasonably can be conceived that would sustain it, there is a presumption of the existence of that state of facts, and one who assails the classification must carry the burden of showing by a resort to common knowledge or other matters which may be judicially noticed, or to other legitimate proof, that the action is arbitrary.

141296 U.S. 176, 56 S. Ct. 159 (1935).

142 Id. at 186 (U.S.), 163 (S. Ct.). Professor Davis, in 1 Administrative Law Treatise (2d ed. San Diego: University of San Diego, 1978) at 449, explains that prior to enactment of the Administrative Procedure Act of 1946, c. 324, 60 Stat. 237 (1946), as am., the presumption applied as an evidentiary presumption attaching to all acts of administrative agencies. The "constitutional jurisdictional fact" doctrine put forward in Crowell v. Benson, supra note 71, had to be understood, accordingly, in light of the presumption of constitutionality. He said:

In making rules of general applicability, agencies were generally free, in absence of special statute, to develop factual materials or not to develop them, as they saw fit, unless a party subject to a rule attempted to rebut the presumption on judicial review. Such freedom of agencies was understood and accepted at the time of enactment of the Administrative Procedure Act in 1946. Nothing in the A.P.A. changed the presumption. 
constitutional. ${ }^{143}$ Third, the presumption is applied as relevant to the adequacy of connection, as a matter of fact, between the curative measures stipulated in the challenged legislation and a constitutionally valid source of power. ${ }^{144}$ It is presumed that the challenged Act is reasonably related, as a matter of fact, to an ostensible source of power.

Professor McWhinney's challenge may not have roused the presumption of constitutionality from its dormant posture in Canadian law. It certainly was not applied by Canadian courts as an evidentiary presumption, and Professor Hogg, in 1977, was undoubtedly correct in writing: "It cannot be said that a presumption of constitutionality [in a factual sense] has been explicitly recognized in Canada as a general principle of judicial review."145

Like the Taj Mahal, this statement is a great monument erected just before the collapse of the era that it glorified. The Supreme Court of Canada in the last two years boldly has fashioned a Canadian version of the doctrine and has forcefully applied the presumption of constitutionality in an evidentiary sense. The irrepressible conclusion from the decided cases signifies a major transformation in Canadian constitutional law, and if (to anticipate likely future developments) the "naturalization" of the presumption is coupled with an entrenched or expanded Bill of Rights constitutional review, Canada will have thrown off the dominance of the immature abstract clash of sovereignties characterizing her constitutional jurisprudence. She will then have taken a giant step forward as a modern federal state.

The presumption of constitutionality was first applied as an evidentiary presumption of fact in CIGOL. Mr. Justice Dickson, in dissenting reasons, said:

143 Adkins v. Children's Hosp. of the Dist. of Colombia, 261 U.S. 525 at 544, 43 S. Ct. 394 at 396 (1923).

This court, by an unbroken line of decisions from Chief Justice Marshall to the present day, has steadily adhered to the rule that every possible presumption is in favour of the validity of an act of Congress until overcome beyond rational doubt.

See also Thayer, The Origin and Scope of the American Doctrine of Constitutional Law (1893), 7 Harv. L. Rev. 129 at 142-44:

The validity of the law ought not then to be questioned unless it is so obviously repugnant to the constitution that when pointed out by the judges, all men of sense and reflection in the community may perceive the repugnancy.... It [the court] can only disregard the Act when those who have the right to make laws have not merely made a mistake, but have made a very clear one,-so clear that it is not open to rational question.

144 Alaska Packers Ass'n v. Industrial Accident Comm'n, 294 U.S. 532 at 547-48, 55 S. Ct. 518 at 524 (1935):

Prima facie every state is entitled to enforce in its own courts its own statutes, lawfully enacted. One who challenges that right, because of the force given to a conflicting statute of another state by the full faith and credit clause, assumes the burden of showing, upon some rational basis, that of the conflicting interests involved those of the foreign state are superior to those of the forum.

See also Railroad Retirement Bd. v. Alton R.R. Co., 295 U.S. 330 at 347 n. 5,55 S. Ct. 758 at 761-62 n. 5 (1935): "When the question is whether the Congress has properly exercised a granted power the inquiry is whether the means adopted bear any reasonable relation to the ostensible exertion of the power."

145 Supra note 110 , at 88. 
Before considering in detail the legislation, one or two observations of a general nature are warranted. This Court is sensitive to the freedom of action which must be allowed to the Legislatures to safeguard their legitimate interests as in their wisdom they see fit. It presumes that they have acted constitutionally. The onus of rebutting that presumption is upon the appellant. Before the Court concludes that the Province has transcended its constitutional powers, the evidence must be clear and unmistakable; more than conjecture or speculation is needed to underpin a finding of constitutional incompetence.146

The remarks were not mere obiter comments. Mr. Justice Dickson went on to examine the evidence proved in the case. He noted that there were concurrent findings in the courts below on the disputed issue of fact-whether the Saskatchewan legislation interfered with federal control over the interprovincial trade in oil. The lower courts had found, as a fact, that the deliveries of oil subsequent to the challenged Saskatchewan legislation continued undisturbed, or at a slightly increased tempo. Thus there had been no interference, as a matter of fact, with the interprovincial stream of commerce in oil. The onus to rebut the presumption of constitutionality pertaining to the legislation had not been discharged.

Application of the presumption of constitutionality in an evidentiary sense was expanded by the full Court in Kruger v. The Queen. ${ }^{147}$ The Court was unanimous in making the presumption of constitutionality the basis of its decision. The question was whether Kruger and Manuel, non-treaty Indians, were subject to British Columbia's Wildlife Act. ${ }^{148}$ Section. 88 of the federal Indian $A C t^{149}$ applies all laws of general application in force in any province to Indians; provincial legislatures are constitutionally incompetent to legislate in relation to Indians directly. Accordingly, the Court had to consider whether British Columbia's Wildlife Act was a law of general application. Two criteria were specified: (1) the Act had to extend uniformly throughout the territory (which it did), and (2) the Act could not, by its consequences, strike harder at one group than another so as to impair the status or capacities of any particular group. Kruger contended that, in cutting down Indian hunting rights, the Wildlife Act went to Indian status and capacities in that it destroyed the traditional Indian way of life. Therefore, the Act could not be a law of general application relevant to Indians.

Kruger's submission raised a question of fact. Did the Wildlife Act impair the status and capacities of Indians? Did that status and those capacities depend, as a matter of fact, on hunting as a way of life? The unanimous Supreme Court, speaking through Mr. Justice Dickson, said:

The presumption is for the validity of a legislative enactment and in this case the presumption has to mean that in the absence of evidence to the contrary the

146 Supra note 5, at 573-74 (S.C.R.), 468 (D.L.R.). The dissent was on other grounds and did not concern application of the presumption. Mr. Justice Martland for the majority largely agreed with Mr. Justice Dickson's statement of relevant constitutional law, but disagreed about its application to the particular challenged legislation.

147 Supra note 6 . Although the reasons in $C I G O L$, supra note 5, were delivered after those in Kruger, ClGOL was heard first.

148 S.B.C. 1966 , c. 55 as am. by S.B.C. 1971 , c. 69 , s. 3.

140 R.S.C. 1970 , c. I-6. 
measures taken by the British Columbia Legislature were taken to maintain an effective resource in the Province for its citizens and not to oppose the interests of conservationists and Indians in such a way as to favour the claims of the former. If, of course, it can be shown in future litigation that the Province has acted in such a way as to oppose conservation and Indian claims to the detriment of the latter - to 'preserve moose before Indians' in the words of Gordon, J.A., in $R$. v. Strongquill (1953), 105 C.C.C. 262, [1953] 2 D.L.R. 264, 8 W.W.R. (N.S.) 247 -it might very well be concluded that the effect of the legislation is to cross the line demarking laws of general application from other enactments. It would have to be shown that the policy of such an Act was to impair the status and capacities of Indians. Were that so, s. 88 would not operate to make the Act applicable to Indians. But that has not been done here and in the absence of clear evidence the Court cannot so presume ... the only question at issue is whether the Act is a law of general application. Since that proposition has not been here negatived, the enactment would apply to Indians ex proprio vigore.160

The crucial point to notice is that the Court squarely applied the presumption of constitutionality to create a presumption of fact. As in Lindsley v. Natural Carbonic Gas Co., ${ }^{151}$ all facts necessary to support the challenged act were presumed. The Court here presumed that the Wildlife Act was necessary as a matter of fact to maintain effective wildlife resources, but the Court went one step further. It specified precisely the kind of facts that must be proved in order to overcome the presumption, and allowed that proof of such facts would affect the Wildlife Act's constitutionality.

In Montcalm Construction Inc. v. Minimum Wage Commission, ${ }^{152}$ Montcalm Construction, a Quebec firm, objected to the application of Quebec's Minimum Wage $A t^{153}$ to its employees engaged in construction work at Mirabel airport. Montcalm's submission was that the construction project and the relevant employees were part of a federal undertaking integrally involved in aeronautics. The principal issue, as in Kruger, turned squarely on a question of fact. Mr. Justice Beetz underlined that point and, in the absence of an adequate evidentiary record, applied the presumption of constitutionality to supply the disputed facts.

The record reveals little with respect to the nature of Montcalm's business or operation. All we know from the admissions made by the parties is that Montcalm is a construction undertaking.... Given these circumstances, we have no choice but to presume that Montcalm's business is that of an ordinary building contractor subject to the conditions of work generally prevailing in the construction industry and of which we are entitled to take cognizance in so far as they are common knowledge. If the facts were otherwise, it was incumbent upon Montcalm to allege and prove them. . $^{154}$

The significant point is that the Court here presumed all facts necessary to make the Quebec Act constitutionally valid as applied to Montcalm Construction.

The importance of this holding cannot be overestimated. Once again,

150 Supra note 6, at 112 and 117 (S.C.R.), $439-40$ and 443 (D.L.R.), 382-83 and 386 (C.C.C.).

151 Supra note 89.

152 Supra note 6.

153 R.S.Q. 1964, c. 144.

154 Supra note 6, at 11 (N.R.), 657-58 (D.L.R.). 
as in CIGOL and Kruger, the presumption of constitutionality is applied squarely as an evidentiary presumption. The presumption here means, as a matter of fact, that Montcalm is an ordinary contractor, and not a contractor integrally involved in aeronautics. If Montcalm could prove affirmatively that it was integrally involved in aeronautics, it would be part of a federal undertaking for the purposes of the Quebec Labour Act while engaged in construction work at Mirabel, and the result would be different. The onus of building a factual record is on Montcalm; all turns on the facts and, in the absence of adequate factual support for the allegation of constitutional incompetence, the presumption of constitutionality governs the result. Further, as in Kruger, the facts necessary to overcome the presumption are precisely specified by the Court. Nothing could be a more stark example of the new role and importance given by the Supreme Court to the presumption of constitutionality.

\section{Presumption of the Existence of all Necessary Facts}

It seems clear that the Supreme Court conceives the evidentiary branch of the presumption in the first American sense explained above-as a "presumption ... of factual conditions supporting the legislation."155 In Kruger the Court presumed that the Wildlife Act was necessary to maintain effective hunting resources in the province. In Montcalm Construction, the Court presumed that Montcalm Construction was not integrally related to an aeronautics undertaking. Both cases illustrate the principle by which all facts necessary to support validity will be assumed to exist.

American cases suggest a "reasonableness" limit to the presumption as used in this way. The court will presume supporting facts that reasonably can be conceived. ${ }^{156}$ If it is unreasonable to suppose the existence of necessary facts, the presumption's force is exhausted and the legislation must fall. For example, if it were unreasonable for the court to presume that Montcalm Construction was not integrally related to aeronautics undertakings, the reasonableness requirement would have destroyed the presumption's operation to create the necessary factual foundation for validity. The case would have had a different result. Counsel who fails to amass an adequate evidentiary record may be able to rely on the reasonableness requirement to save his case. It seems clear, however, that this is an emergency switch to be thrown when all else has failed.

The evidentiary branch of the presumption, so conceived, has its greatest significance in forcing attacking counsel to build a record. ${ }^{157}$ In view of the cases already discussed, it would be perilous for attacking counsel to come to court armed only with a briefcase full of Privy Council and Supreme Court precedents. He had better amass all relevant facts whether the complaint

155 Borden's Farm Products, supra note 97, at 209 (U.S.), 191 (S. Ct.). See also Note, The Presumption of Constitutionality Reconsidered (1936), 36 Colum. L. Rev.

283, where the author explains the presumption in the same way.

150 See Notes 139-40, supra.

157 Note, The Presumption of Constitutionality (1931), 31 Colum. L. Rev. 1136 at 1148: 
be ultra vires or inoperability for conflict with paramount federal legislation. Counsel may overstuff himself on precedents, but the Court has indicated that it will diligently count the calories. What the judges want are particulars of the challenger's case: what are the facts? The question cannot be ignored with impunity. If counsel refrains from presenting essential constitutional facts, the Court will presume away his success.

It is equally true that as adequacy of the factual record becomes more apparent, the signficance of the presumption of constitutionally greatly diminishes. ${ }^{158}$ The presumption operates most cogently in the absence of facts; as the relevant facts are brought before the court, the presumption winds down. The evidentiary branch of the presumption is not a doctrine geared to make success on a constitutional issue any more or less difficult; it is employed by the court to insure completeness and rigour in presentation of the constitutional issue. Thus, the presumption is a doctrine particularly well suited to ameliorate complaints made about the abstractness of Canadian constitutional decisions. Its use in Canada at the time is especially desirable.

The "abstract clash of sovereignties" as a leading feature of Canadian constitutional jurisprudence is doomed. The three cases discussed above reveal the immense ground that it has given up to factual issues and a new pragmatic spirit. Narrower constitutional rulings with all that they imply may be expected from the Supreme Court in future. The driving force behind all of this is the presumption of constitutionality.

\section{Rational Connection}

Canadian constitutional reasoning, with few exceptions, has been onedimensional. The courts consider a clash of governmental interests as such interests are tested against the design of the B.N.A.Act. In the United States, constitutional reasoning has a second dimension. Governmental sovereignty is limited. Powers not expressly delegated to governmental authority are reserved to the people as fundamental rights and freedoms with which no government is competent to interfere. The courts consider the reach of governmental power as tested against certain fundamental freedoms elaborated in the American Bill of Rights. Although Canada has enacted her own statutory Bill of Rights, ${ }^{150}$ it is fair to say that, with limited exceptions, the

But, as a means of forcing attorneys to present the complete background of a case to the Supreme Court, and of thus protecting legislative action from judgments of invalidity based on insufficient information, the presumption of constitutionality has great possibilities.

See also Biklé, Judicial Determination of Questions of Fact Affecting the Constitutional Validity of Legislative Action (1924), 38 Harv. L. Rev. 6 at 21-22. 291-92:

158 Note, The Presumption of Constitutionality Reconsidered, supra note 155, at

The pulls of an expanded judicial notice and deference to findings based on evidence, though contrary in one respect, have this in common: they both result in the presence of facts before the Court, and thus reduce the sphere in which the presumption may operate. As counsel become more alert to present the facts upon which they rely, there will be less need for a presumption of facts.

159 The Canadian Bill of Rights, S.C. 1960 , c. 44. 
event has not fully added another dimension to our constitutional law or fundamentally changed our conception of governmental power.

Because the weighing of interests in the United States must be done in two dimensions-as between governmental sovereignties and also as between governmental power and citizens possessing a protected area of human space 160 -American courts have had to be much more astute in finding a reasonable connection between challenged acts and ostensible sources of government power. In Muller v. Oregon, ${ }^{161} \mathrm{Mr}$. Louis Brandeis, as counsel, first opened the door to establishing this relation as an issue of fact. In that great case, Mr. Brandeis used an amalgam of social science statistics compiled by agencies and student researchers, and legislative committee reports to establish the relationship between a woman's health and her hours of labour. Facts of this type have been most useful in fleshing out with concrete particulars disputes where the alleged constitutional defect involves invasion of a Bill of Rights interest. Thus in United States v. Carolene Products Co.,162 for example, Brandeis brief facts were highly relevant to the court in answering a complaint that a statute prohibiting interstate transportation of milk was a denial of due process. Such data were also relevant in the great school segregation cases, Sweatt v. Painter ${ }^{163}$ and Brown v. Board of Education. ${ }^{164}$ In Sweatt, Mr. Thurgood Marshall, counsel for the attackers, was especially clear in explaining to the Court the relevance of social scientific data to his allegation of constitutional defect. He said:

[W] have the right to show their unconstitutionality.... There are several ways of going about proving unconstitutionality of statutes. They haven't shown any line of reasoning for the statutes. I imagine they are relying on the presumption that the statutes are constitutional. If they are relying on that we have a right to put in evidence to show that segregation statutes in the State of Texas and in any other state, actually when examined, and they have never been examined in any lawsuit that I know of yet, have no line of reasonableness. There is no understandable factual basis for classification by race, and under a long line of decisions by the Supreme Court, not on the question of Negroes, but on the 14th Amendment, all courts agree that if there is no rational basis for the classification, it is flat in the teeth of the 14th Amendment....185

There can be no doubt that the two axes-federalist disputes and Bill of Rights disputes-are different. Conflicts over the allocation of power, as explained above, raise issues of constitutional policy. Social science data are not critical to informed judicial resolution, nor is there any compelling necessity to examine social science data to discover whether, as a matter of constitutional policy, the challenged act exhibits a rational connection to an

100 The language is that of Professor Charles Reich. See his essay, The New Property (1964), 73 Yale L.J. 733. The concept has been exceptionally influential in the developing American constitutional right to privacy: see, e.g., Roe v. Wade, 410 U.S. 113, 93 S. Ct. 705 (1973); and Doe v. Bolton, 410 U.S. 179, 93 S. Ct. 739 (1973).

161208 U.S. 412, 28 S. Ct. 324 (1908).

162304 U.S. 144, 58 S. Ct. 778 (1938).

163339 U.S. 629, 70 S. Ct. 848 (1950).

164347 U.S. 483, 74 S. Ct. 686 (1954).

${ }^{105}$ As quoted from the trial record in Kohn, Social Psychological Data, Legislative Fact, and Constitutional Law (1960), 29 Geo. Wash. L. Rev. 136 at 140. 
ostensible source of power. Economic data, however, certainly may be useful; in Canada it seems clear that such evidence, where relevant, must be produced. Mr. Justice Laskin's complaint about the lack of supporting economic data in A.G. Man. v. Manitoba Egg and Poultry Association ${ }^{160}$ ripened into judicial directions to supply such data in the Reference re Anti-Inflation $A c t^{\text {167 }}$ The presumption of constitutionality could usefully be applied in such cases to throw an onus on the attacker to build an adequate economic record.

Bill of Rights disputes raising broad issues of social policy differ. However, they are not (or not yet) characteristic of Canadian constitutional law.168 It is helpful to underline that point, for the call for Brandeis brief advocacy implies a wholesale restructuring of Canadian constitutional litigation in point of content; it implies a shift away from federalist disputes towards fundamental freedoms disputes. The Brandeis brief is not an end in itself.

In saying this, one must not overlook the importance of Curr v. The Queen. ${ }^{169} \mathrm{Mr}$. Justice Laskin in that case masterfully outlined the scope of American due process theory, but he refused to hold that compulsory breathalyzer tests violated due process guarantees in section $1(a)$ of the Canadian Bill of Rights ${ }^{170}$ without proof of adequate supporting data. In other words, the attacker was defeated by a presumption of constitutionality for failure to bring sufficient constitutional facts before the Court.

Notwithstanding that Canadian constitutional law lacks (for the time being) a strong Bill of Rights flavour, there is reason to conclude that the rational connection test, in some cases, will be the chief result of applying the presumption of constitutionality in an evidentiary sense. Mr. Justice Dickson in Kruger suggested that the presumption required attacking counsel to establish that the policy of the challenged act was to impair the status and capacities of Indians. That is quite a different thing from proving that the effect of the Act, as a matter of fact, accomplished that result. "Policy" and "effect" are certainly not congruent. One would have thought that policy could be established by showing a rational connection between the challenged act and a constitutionally valid purpose. Even if the act misfired-did not have the desired effect-the policy, if rationally connected to an ostensible source of power, would still provide constitutional support. The presumption is that

160 Supra note 6.

187 Supra note 5.

168 A good illustration of this proposition is provided by the short shrift given by the Supreme Court of Canada to the constitutional issue presented in Morgentaler v. The Queen, [1976] 1 S.C.R. 616, 53 D.L.R. (3d) 161, 20 C.C.C. (2d) 449. Counsel had prepared considerable evidence as to inequality of access to abortion; the Court largely disregarded it. In Saumur v. City of Quebec, [1953] 2 S.C.R. 299, [1953] 4 D.L.R. 641, 106 C.C.C. 289 , counsel for the appellant succeeded but was denied an award of costs for presenting Brandeis brief data in his factum. I know of no other circumstances where this was done, but I might remark that I have read my share of long and irrelevant facta where costs were not withheld-and this includes facta longer, and, in my personal view, more irrelevant, than the Saumur factum.

169 [1972] S.C.R. 889, 26 D.L.R. (3d) 603, 7 C.C.C. (2d) 181.

170 S.C. 1960 , c. 44 . 
the act is rationally connected to a constitutionally valid purpose or source of power.

\section{OVERCOMING THE PRESUMPTION}

\section{A. Position of the Attacker}

An attacker of legislation may have a factual onus of proof to discharge. Four mechanisms are available to him to overcome the burden created by the presumption of constitutionality. They are: (1) judicial notice, (2) proof of fact at trial, (3) proof of fact in the appellate factum, and (4) proof by extrajudicial specialized research agencies.

\section{Judicial Notice}

Counsel may invite the court to take judicial notice of relevant facts in a variety of ways: he may present such facts in oral argument, in memoranda, in facta or in appendices to facta. Whole books have been photocopied by counsel and accepted by the Supreme Court of Canada as factum appendices, but the court does not need counsel's invitation to take judicial notice of relevant facts. It can and does conduct its own research. As Mr. Justice Frankfurter said in argument during Briggs v. Elliott:

Can we not take judicial notice of writing by people who competently deal with these problems? Can I not take judicial notice of Myrdal's book without having him called as a witness? ... How to inform the judicial mind, as you know, is one of the most complicated problems. It is better to have witnesses, but I did not know that we could not read the works of competent writers. ${ }^{171}$

It appears from dissenting reasons in $C I G O L^{172}$ that the Supreme Court of Canada agrees. The Court there referred to facts pertaining to the elasticity of demand for oil which did not appear in the case or facta filed by counsel. This practice dates from at least the time of Lord Mansfield. In Lewis v. Rucker, Lord Mansfield freely acknowledged going beyond the record for facts:

I thought a good deal of the point, and endeavoured to get what assistance I could by conversing with some gentlemen of experience in adjustments. ${ }^{173}$

171 Transcript of Argument in Briggs v. Elliott, No. 102, in the United States Supreme Court, Oct. term, 1952, at 555-59, as cited in Greenberg, Social Scientists Take the Stand: A Review and Appraisal of Their Testimony in Litigation (1956), 54 Mich. L. Rev. 953 at 966.

172 Supra note 5. See also Note, Social and Economic Facts-Appraisal of Suggested Techniques for Presenting Them to the Courts (1948), 61 Harv. L. Rev. 692 at 697:

Under the guise of judicial notice, some courts have conducted independent researches on their own in order to learn social facts not so notorious and indisputable as to be capable of true judicial notice. They have not usually obtained the information from the primary sources, but rather have had to resort to libraries, experts, government agencies, or even employees of an agency which is a party to the case.

The author is critical of the practice. He points out that it disregards the interests of parties to the litigation who are given no opportunity to be heard.

173 (1761), 2 Burr. 1167 at 1172, 97 E.R. 769 at 772 (K.B.). Justice Brandeis was apparently notorious for out-researching counsel. See Note, The Presumption of Con- 
The practice may be expected to increase. Only a short while ago law journals were not accepted as authorities before the court. Perusal of any recent volume of the Supreme Court Reports demonstrates how far from that position we have come.

What limits, then, are there to judicial notice as a means for bringing facts before the Court? Can adjudicative ${ }^{174}$ disputed facts upon which the constitutionality of challenged legislation depends be noticed judicially? Can facts contradicting a legislative declaration be noticed judicially?

Canadian writers who have grappled with these questions hold the view that judicial notice properly may be taken only of facts which are:

(a) so notorious as not to be the subject of dispute among reasonable men, or

(b) capable of immediate and accurate demonstration by resorting to readily accessible sources of information. 175

The Supreme Court of Canada, in an administrative law setting, has provided support for this proposition. In Pfizer Co. v. Deputy M.N.R. ${ }^{170}$ an administrative tribunal had to decide whether a particular substance was a tetracycline derivative. Tetracycline derivatives were dutiable; non-derivatives were not. During hearings before the Tariff Board, counsel produced evidence as to the derivation process, but the tribunal, in its reasons, decided on the basis of certain scientific texts not produced in evidence and not subject therefore to scrutiny by opposing counsel or cross-examination. The Court held that the Tariff Board Act, ${ }^{177}$ which authorized the tribunal to gather evidence other than by oath or affirmation, did not extend this far. Particularly obnoxious, said the Court, was the want of opportunity to answer or contest the disputed information. Mr. Justice Pigeon stated:

What the Board calls "the actual derivation of tetracycline or oxytetracycline" is not like the usual meaning of words, a matter of which a court or a board exer-

stitutionality Reconsidered, supra note 166, at $290 \mathrm{n}$. 37. See also Denning, The Discipline of Law (London: Butterworths, 1979) at 289.

174 Adjudicative facts are to be contrasted with legislative facts according to a famous distinction originally made by Professor Davis in 2 Administrative Law Treatise (1st ed. St. Paul: West Pub. Co., 1958) at $\$ 15.03$. This is a refined version of the distinction that Professor Davis first put forward in An Approach to Problems of Evidence in the Administrative Process (1942), 55 Harv. L. Rev. 364; and elaborated further in Judicial Notice (1955), 55 Colum. L. Rev. 945.

175 Hogg, supra note 64, at 394, quoting Sopinka and Lederman, The Law of Evidence in Civil Cases (Toronto: Butterworths, 1974) at 374. See also Strayer, supra note 37, at 173:

By the ordinary rules of evidence, a court can take judicial notice only of "notorious" facts or facts of public, general knowledge. While there appears to be a large area of discretion as to what facts the courts will judicially notice, they have frequently limited themselves to matters of which virtually everyone would be aware.

However, both Strayer and Hogg suggest that judicial notice has not been adequate to presentation of legislative facts and may require modification in traditional modes of proof.

176 [1977] 1 S.C.R. 456, 68 D.L.R. (3d) 9.

177 R.S.C. 1970 , c. T-1. 
cising judicial or quasi-judicial authority may take judicial notice. It is clearly a question of fact to be decided on evidence and it has been the subject of evidence by qualified expert witnesses at the hearing. The negative evidence given by appellant's expert witnesses was not contradicted by respondent's experts who were heard before the Board and questioned on the point. The two texts mentioned by the Board were not mentioned. Counsel for the respondent did not put them before appellant's witnesses in cross-examination as he did for other texts. In my view, it was a grave error to rely on those texts in its decision as against the oral evidence. 178

The point made by Mr. Justice Pigeon is acute, and crucial in the administrative law setting. Clearly, one must assume an aroused sense of respect for the audi alteram partem rule when the tribunal purports to take judicial notice of disputed adjudicative facts. However, three caveats are warranted in transposing the administrative law principle to a constitutional setting. First, in constitutional litigation the judicial notice doctrine takes a certain colouring from the presumption of constitutionality. The court, in sustaining legislation, does not act on strict proof of facts, but rather on reasonable conjecture-it will presume the existence of any state of facts necessary to support the challenged statute if reasonable to do so. There would be an insuperable burden on the attacker (or judicial notice would be eviscerated) if the court required complete accord on judicially noticed adjudicative or legislative facts. Second, approximately one-third of major constitutional issues in Canada are resolved by the reference procedure; there is no trial at which facts may be proved by the adversary process. Judicial notice necessarily takes on added importance as a fact-gathering device. Third, constitutional issues that arise in private litigation oppose governmental interests and purport to define the limits of governmental power. Thus, if a wide ruling emerges, the court must be sufficiently sophisticated to consider all relevant points of constitutional fact and policy. An informed and intelligent constitutional review jurisdiction would be truncated if the court were limited to factual presentations of the parties. Provincial taxing competence, for example, ought not to depend entirely upon legislative facts adduced by counsel before a provincial court where the narrow issue is a demand for a few dollars in succession duties. ${ }^{170}$

These considerations highlight the need to balance an expanded use of judicial notice with adequate procedural safeguards for the rights of private litigants and attorneys-general to be heard on disputed questions of fact. It is crucial that the court robustly conceive its power to notice facts judicially; it ought not to limit itself to facts so obvious as not to be the subject of dispute among reasonable men. Fifteen years ago, for example, it was so notorious as to be indisputable that full frontal nudity in the movies or on stage was obscene. However, things change, opinions pass away; the hardest held and felt beliefs dissolve into superstition. That is what characterizes the progress of human enlightenment. The courts play an important

178 Supra note 176, at 463 (S.C.R.), 15 (D.L.R.).

178 The point is mitigated by statutory provision for notice to the provincial attorney general and the Attorney-General of Canada when constitutional points are raised. It is not completely answered, however, for provincial representation is by no means always made. Rarely do all of the provinces intervene. 
dispute-settling and educative role in forming reasoned opinions. In so doing they aid emancipation of the mind from superstition, and the steady growth of enlightenment in the legal order. If the courts were to notice only those facts and opinions on which all agree they would abandon that high duty. Matters such as the social value of nude representation in art do not admit of proof beyond a reasonable doubt. If the presumption of constitutionality requires this, it cannot be adequately overcome in a trial type setting. That is why the constraints of judicial notice must be relaxed in constitutional cases. The point takes on added relevance in Bill of Rights disputes.

It is crucial, however, that procedural safeguards accompany expansion of judicial notice. Most importantly, the litigants and attorneys-general affected ought to be given due notice and a fair opportunity to contradict any facts intended to be made the subject of official notice. As long ago as 1923, Professor Wigmore suggested that facts judicially noticed could and should be disputed.

That a matter is judicially noticed means merely that it is taken as true without the offering of evidence by the party who should ordinarily have done so. But the opponent is not prevented from disputing the matter by evidence, if he believes it disputable. It is true that occasionally a Court is found declaring a thing judicially noticed and at the same time refusing to listen to evidence to the contrary; but usually this is in truth laying down a new rule of substantive law by declaring certain facts immaterial. ...180

The extent of facts properly made the subject of judicial notice will vary with the circumstances of each case; the procedure for disputing the facts will have to be worked out on a case-by-case basis. ${ }^{181}$ Finding the appropriate balance between an expanded use of judicial notice and adequate procedural protections is a great and important challenge for our constitutional jurisprudence. Certainly not all trivia in the judge's experience need to be set forth on the record or drawn to counsel's attention. However, (1) the more the judicially noticed facts are crucial to the constitutional issue, (2) are disputed, and (3) are facts that the parties reasonably can develop, the more the court ought to notify counsel and allow an opportunity to answer. ${ }^{182}$

\section{Proof of Facts at Trial}

Judical notice has its limits. The more complex and disputed the facts, the less reliable is judicial notice as a means for bringing relevant facts before the court. The court's authority and prestige is at risk if it gets too far ahead of counsel in the fact-finding process. ${ }^{183}$ The problem can be ameliorated by

$1805 \mathrm{~A}$ Treatise on the Anglo-American System of Evidence in Trials at Common Law (2d ed. Boston: Little, Brown, 1923) at \$2567 [hereinafter Wigmore on Evidence].

181 This procedure was adopted in the Reference re Anti-Inflation Act, supra note 5, and described in Hogg, supra note 52, at $396 \mathrm{ff}$. See also the discussion by the McRuer Commission, 1 Inquiry into Civil Rights (Toronto: Queen's Printer, 1968) at 50-51.

182 See generally Davis, Judicial Notice, supra note 174, at 983 . The article is exceptionally useful and enlightening.

183 Professor Fuller put the point in this way:

[The] moral force of a judgment is at maximum if a judge decides solely on the basis of arguments presented to him. Because if he goes beyond these he will lack 
presenting the factual issue in the trial court for resolution through the ordinary evidentiary process. The range of constitutional issues brought before the courts and their technical complexity is startling; the result has often been cause for considerable optimism. In Ryan v. The Attorney General ${ }^{184}$ voluminous quantities of technical literature on fluoridation and its effects were considered by the Irish Court. Many expert witnesses were called and testified at length. The trial court did an admirable job of sorting the reliable literature from the tendentious; it did an equally admirable job of testing the experts' credibility. The court's reasons are lucid and sophisticated; they draw heightened attention to the trial forum as a means for proving constitutional facts.

In Canada, it seems clear that the trial forum is available for presentation of constitutional facts. In A.G. Can. v. Reader's Digest Association Mr. Justice Cartwright said: "In the case at bar it will be open to the parties to lead evidence to show the circumstances to which the impugned sections are to be applied. ..."185 In the Bank Taxation Reference Lord Maugham went further. The Court, he said, could require evidence; presumably the holding extends to trial courts:

The next step in a case of difficulty will be to examine the effect of the legislation: .... For that purpose the Court must take into account any public general knowledge of which the Court would take judicial notice, and may in a proper case require to be informed by evidence as to what the effect of the legislation will be.188

In Lower Mainland Dairy Products Board v. Turner's Dairy Limited the Supreme Court agreed with the statement in the British Columbia Court of Appeal that trial judges possess a wide judicial discretion to determine whether the court should be informed by evidence of the statute's effect. Mr. Justice Taschereau said:

In certain cases ... extraneous evidence is required to facilitate the analysis of legislative enactments.... The true purposes and effect of legislation ... must be considered....187

Notwithstanding these holdings, problems have arisen. Several Canadian trial courts have refused to admit factual evidence bearing on the constitutional issue. Extrinsic materials to show the effect of taxing legislation were refused by the Saskatchewan Court of Appeal in Cairns Construction Limited v. Saskatchewan ${ }^{188}$ and by both the trial court and Court of Appeal in

guidance and may not understand interests that are affected by a decision outside the framework.

as cited in Wyzanski, A Trial Judge's Freedom and Responsibility (New York: Ass'n of the Bar of New York, 1952) at 19. See also Note, The Presentation of Facts Underlying the Constitutionality of Statutes (1936), 49 Harv. L. Rev. 631 at 632-33; and Denman, Comment on Trials of Fact in Constitutional Cases (1935), 21 A.B.A.J. 805.

184 Supra note 7.

185 Supra note 46, at 792 (S.C.R.), 312 (D.L.R.).

186 Supra note 35, at 130 (A.C.), 438-39 (D.L.R.).

187 [1941] S.C.R. 573 at 583, [1941] 4 D.L.R. 209.

188 (1958), 16 D.L.R. (2d) 465, 27 W.W.R. 297 (Sask. C.A.), aff'd on the merits, [1960] S.C.R. 619. 
CIGOL. ${ }^{189}$ One ground of appeal in the latter case squarely put the issue to the Court. It was said that the Saskatchewan courts erred in refusing to admit the evidence. Neither the majority nor the minority in the Supreme Court commented on that submission. In Central Canada Potash v. Government of Saskatchewan ${ }^{180}$ a wide variety of extrinsic materials were admitted by tho trial judge but excluded by the Court of Appeal. Complaint about the exclusion was made to the Supreme Court of Canada. Once again, the Supreme Court avoided the issue. Chief Justice Laskin said only:

I am content to proceed on the basis of these findings [admitted by the Court of Appeal] and on an examination of the Regulations, directives and licenses involved in the prorationing and price fixing scheme, without any further regard for any of the other extrinsic evidence adduced before the trial judge.101

Chief Justice Laskin, it must be said, did try to explain away Cairns Construction in his reasons in the Reference re Anti-Inflation Act. Extrinsic materials, he argued, could be of no help in taxing disputes because the economic evidence of the tax was irrelevant to the test for validity. ${ }^{102}$

Explaining away all of the relevant case law was a formidable task; it led the Chief Justice to this conclusion:

No general principle of admissibility or inadmissibility can or ought to be propounded by this Court, and that the questions of resort to extrinsic evidence and what kind of extrinsic evidence may be admitted must depend on the constitutional issues on which it is sought to adduce such evidence.103

One might be tempted to conclude from this that the availability of trial procedure for the introduction of constitutional facts is uncertain in Canada. But the trend is clear and is in the direction of wider admissibility and wider employment of the trial procedure in bringing forward relevant constitutional facts. Cairns Construction poses little difficulty; evidence as to the effect of the taxation was excluded in that and similar taxing disputes because the courts have created a legal fiction. The test for validity of provincial taxing

180 Supra note 5.

190 Supra note 5. Chief Justice Culliton of the Saskatchewan Court of Appeal described what was admissible in this language in his judgment on appeal, $(1977), 79$ D.L.R. (3d) 203 at 217, [1977] 1 W.W.R. 489 at 504:

Evidence as to the circumstances leading up to the adoption of the Regulations and evidence relating to the potash resources of the Province, the history of the industry, its productive capacity, the demand for its production, the state of the market and the economic problems which it faced, were all properly admissible. Such evidence gave "the underpinning for the issues" as Laskin, J. (as he then was) stated in A.G. Man. v. Manitoba Egg \& Poultry Ass'n et al. . . Too, such evidence sets out the evil sought to be remedied.

191 Id. at 72 (S.C.R.), 629 (D.L.R.).

192 The test for determining constitutional validity of a provincial taxing statute is the general tendency of the tax as commonly understood. The ultimate incidence of the tax is not relevant. See Magnet, The Constitutional Distribution of Taxation Powers in Canada, supra note 121 , at 487 . However, the courts are by no means consistent on this point. Mr. Justice Ritchie in Simpsons-Sears Ltd. v. Prov. Sec'y of N.B., supra note 21, squarely based his reasons on the ultimate economic incidence of the taxation of promotional materials considered in that case: see Magnet, op. cit., at 325.

${ }^{193}$ Reference re Anti-Inflation Act, supra note 5, at 389 (S.C.R.), 468 (D.L.R.). 
statutes is the general tendency of the tax as commonly understood; the actual economic incidence of the tax cannot contradict that test. The reason why the fiction has been created is in order to enlarge provincial taxing powers-to stretch them judicially beyond what was contemplated by the founding fathers. Provincial revenue-generating capacity has thus been brought into line with expanded provincial legislative responsibilities, such that the exclusion is necessary and proper. It is a means for the court to modernize the distribution of taxing powers, but it is a very special case. As a general rule, the trial forum ought to be available to counsel trying to overcome the burden created by the presumption of constitutionality.

\section{Proof in Appellate Facta}

Because so many important Canadian constitutional issues come before the Court by way of references, the problems of fact-gathering at the appellate level assume paramount importance. There is no trial; there is no adversarial evidentiary process as understood by civil litigation practitioners. Accordingly, methods have had to be devised for bringing constitutional facts before the Court and for contesting disputed adjudicative facts. In the Eskimos Reference $^{104}$ the Supreme Court, by order, appointed the Court's Registrar as a tribunal before whom the parties could present all evidence deemed relevant. Evidence was proferred and accepted from historians, social scientists, and scholarly and official documents to elucidate the meaning of the term "Indians" (and its possible inclusion of the Inuit) as used in the B.N.A. Act. In the Reference re Anti-Inflation Act, ${ }^{105}$ pursuant to order of the court, the Attorney-General of Canada was allowed to include extrinsic evidence in the case while others were allowed to attach appendices to their facta. Additional material was permitted to be filed by a specific date. ${ }^{196}$ This gave an opportunity to answer or contest disputed points. It has been remarked that the procedure adopted in the Eskimos Reference resulted in a well informed opinion; ${ }^{197}$ mild disapproval has been voiced about the results of the procedure adopted in the Reference re Anti-Inflation Act. ${ }^{198}$

Perhaps the most important development respecting presentation of constitutional facts in the reference procedure is the complaint made by $\mathrm{Mr}$. Justice Laskin in the Manitoba Egg Reference. "The utility of the Reference," he said, "is seriously affected because there is no factual underpinning for the issues. ..."199 The complaint had been made forty years earlier by Mr. Justice Duff in the Water Powers Reference in equally strong language, ${ }^{200}$ but Mr. Justice Laskin went further. He noted three ways in which evidence could

194 [1939] S.C.R. 104, [1939] 2 D.L.R. 417.

195 Supra note 5.

106 See Hogg, supra note 64, at 402-07.

197 Strayer, supra note 37, at 180.

108 See Hogg, supra note 64, at 405-07.

198 Supra note 6, at 704 (S.C.R.), 181 (D.L.R.).

200 [1929] S.C.R. 200 at 224 and 227, [1929] 2 D.L.R. 481 at 495 and 497. See also Davison, The Constitutionality and Utility of Advisory Opinions (1938), 2 U. Toronto L.J. 254 at 270. 
be brought before the Court. One of those ways included an offer of evidence by counsel to indicate the circumstances prompting the reference. Thus, the court is anxious to have such materials at the appellate court level, and will, in consultation with counsel, ${ }^{201}$ devise procedures for its presentation and rebuttal. One could hardly ask for more.

\section{Specialized Research Agencies}

Judicial notice, adversary trial procedures, and newly improvised appellate techniques ensure formidable fact-gathering potential in constitutional litigation, but significant difficulties remain. Constitutional facts tend to be specialized and highly technical; often they are politically charged. In the Reference re Anti-Inflation Act, ${ }^{202}$ for example, the Court had to understand the significance of inflation to the national economy. In the Manitoba Egg Reference $^{203}$ the Court called for detailed facts as to production, marketing and consumption of eggs in Canada so as to test the effect of a challenged legislative scheme on those activities. Situations such as these involve predictive theories and highly abstract models to appreciate the significance of individual details. Problems of presentation multiply. Fact interpretations may involve a choice between competing scientific theories, which is the legitimate domain of experts.

The legislature uses a variety of specialist agencies and experts, including its own personnel, in investigating constitutional facts prior to enactment. Part of the documents thereby generated may be judicially noticed or included in the appellate case or factum. ${ }^{204}$ However, suggestions have been put forward that specialized research agencies under curial rather than legislative control be employed in the fact-gathering process. ${ }^{205}$

Nevertheless it is hard to see that a permanent research agency is desirable. Potential factual issues touch all fields of human knowledge, so the agency would have to be highly expert in many areas and thus be of a large size. However, highly technical constitutional-fact questions do not occupy much of the Court's docket and therefore the agency would have relatively little to do. That implies poor motivation and institutional decay. It implies, too, great costs for relatively little benefit. It would be much better to bring

201 Professor Hogg, who acted as counsel for the Canadian Labour Congress in the Reference re Anti-Inflation Act, notes that on the C.L.C.'s proposal to introduce extrinsic evidence, Chief Justice Laskin, prior to giving directions for presentation and rebuttal, met with counsel several times. See supra note 64, at 399.

202 Supra note 5.

203 Supra note 6.

204 See, e.g., the Reference re Anti-Inflation Act, supra note 5, which involved a government white paper on infiation.

205 See, e.g., North, "Note and Bibliography on Judicial Fact Finding," in Hall, ed., Readings in Jurisprudence (Indianapolis: Bobbs-Merrill, 1938) 1138 at 1148-49; Note, Social and Economic Facts-Appraisal of Suggested Techniques for Presenting Them to the Courts (1948), 61 Harv. L. Rev. 692 at 700-01; and Note, The Presentation of Facts Underlying the Constitutionality of Statutes (1936), 49 Harv. L. Rev. 631 at $634 \mathrm{n} .25$. 
directly before the court or its organs experts fresh from universities, governments, or industries.

In any event, no extra-curial research agency could hope to develop competence in everything. At best, it could be a streamlined tribunal of fact, sifting the work of others. However, a unit so conceived does not need separate creation. Existing court systems, if upgraded, are adequate. Funds could be employed better by improving, supplementing and redesigning present structures. Research personnel could be added to the Court's library staff and the Registrar's office. The law clerk staff could be expanded and those having specialized competence could be assigned in-depth research projects. $^{206}$ That would generate a research unit of consequence.

It would make more sense to deal with fact-gathering procedures on a case-by-case basis. The Supreme Court of Canada, pursuant to section $103(1)(f)$ of the Supreme Court $A c t^{207}$ has rule-making power with respect to fact investigations in references. Rules could be made as necessary to facilitate the fact-gathering process in any particular case. ${ }^{208}$ Experts could be brought before the Court, a rump bench, or a court functionary ${ }^{209}$ in an adversarial or inquisitorial setting. Expert reports in technical and specialist fields could be commissioned. Experience with these and other techniques should demonstrate whether they are adequate or whether further factgathering capacity needs to be added to the Court's arsenal.

\section{B. Position of the Government}

When legislation is challenged, all facts necessary to support it will be presumed; a regular legislative purpose and intent will be presumed and an intra vires operation of the statute will be presumed as a matter of fact and construction. If the case turns on one or more of these, counsel can remain seated until the attacker has made out a sufficient case. He may rely on the presumption of constitutionality.

However, reliance solely on the presumption is neither desirable nor safe. Counsel would be tempting the court. As already explained, the court is not too timid to make its own investigations and resort to judicial notice. Though there is a general presumption of constitutionality, the court will not

206 At present, ten law clerks are employed by the Supreme Court of Canada. One is assigned to each judge and one is assigned to the Registrar. Moreover, additional tasks are being assigned to them. Summaries of cases used to be the responsibility of the Chief Justice's executive assistant; in 1976 it was transferred to the law clerks.

207 R.S.C. 1970 , c. S-19.

208 As was done in $\operatorname{Re}$ Truscott, [1967] S.C.R. 309, 62 D.L.R. (2d) 545, [1967] 2 C.C.C. 285. See Professor Hogg's discussion, supra note 64, at 393 n. 64.

209 As reported in Lane, supra note 129, at 882-83, the High Court Rules, O. 38, especially rr. 1-4, make provision for the High Court to appoint:

but only on application made, an independent expert to inquire into and report on a question of fact or opinion on such matters as science, law, medicine, engineering, accountancy, architecture, and the like. A party may cross-examine the expert on his report. The report may be accepted by the parties or, if not, may become background information for the Court. 
shut its eyes to the obvious nor shrink from diligently searching out the less than obvious but crucial aspects of the case. Counsel for the government is well advised to bring before the court such facts as sufficiently illustrate his case. The presumption of constitutionality tilts the risk of failure due to inadequate presentation towards the attacker, but the presumption does not insure that he will lose for substandard demonstration of the factual issues.

Professor Freund has suggested an additional reason why government counsel ought not to place undue faith in the presumption:

In the first place, it may be questioned whether the advocate arguing in favor of the validity of a statute should take the burden of supporting it by a mass of factual data instead of relying on the presumption of constitutionality. Is not the government advocate who submits a Brandeis brief tempting the court to decide the case without the benefit of the presumption-to decide it, that is, as if the burden of sustaining the statute were upon the proponent? This objection needs to be raised, but it seems to me that it can be answered. The presumption of constitutionality need not be lost sight of; but even a court which relies on the presumption in sustaining a statute does so more confidently and more comfortably if some factual foundation has been established for the validity of the law. And $I$ take it that it is the function of counsel not merely to provide the legal doctrine for deciding the case his way, but to make the court feel comfortable in doing so.210

A prime reason behind the factual branch of the presumption is to insure that an adequate record is presented to the courts. That is why, in situations such as a motion to dismiss, the force of the presumption may be attenuated considerably. Pleadings cannot adequately state factual conditions. ${ }^{211}$ There may also arise cases where the government alone is in possession of all relevant facts. Such cases may eviscerate the presumption's force; they may even occasion reversal. The record would be built most effectively if the government were to resist disclosure at its peril..$^{212}$

Counsel can best satisfy the need for facts by relying on the legislature: royal commissions, legislative declarations, committee reports, departmental reports, commissioned studies-all of these are prime material. The legislature and its organs are the most important fact-gathering force in the country, and the government advocate should never lose sight of this as he contemplates the advantages lent him by the presumption of constitutionality.

210 Freund, supra note 98 , at 87-88.

211 See Note, The Presentation of Facts Underlying the Constitutionality of Statutes, supra note 205, at 635 :

The desirability of concretely presenting constitutional facts in evidence makes doubtful the wisdom of rigidly applying the presumption of constitutionality when the case arises upon a motion to dismiss. The pleader, aided by judicial notice, must state facts sufficient to invalidate the statute, and a general averment that it is arbitrary and unreasonable is insufficient. But, since it is well nigh impossible to set forth in pleadings a full statement of complicated conditions, the constitutionality of legislation may often be established upon an inadequate basis.

212 Reversal of the presumption has occurred in the United States although not for the reason suggested. Legislation that classifies by racial criterion occasions reversal of the presumption. See Kohn, Social Psychological Data, Legislative Fact, and Constitutional Law (1960), 29 Geo. Wash. L. Rev. 136 at 143. 


\section{Standard of Proof}

The evidentiary branch of the presumption may affect attacking counsel in two ways: (1) it may create a presumption that a rational connection exists between the challenged act and the legislature's catalogue of powers, and (2) it may create a presumption that all facts necessary to support the challenged exercise of power exist. The legislation will fall if either of these presumptions can be overcome.

When attacking counsel chooses to prove that a challenged act is not rationally connected to an ostensible source of legislative authority, he has a heavy burden. Different considerations arise when he seeks to demonstrate that necessary constitutional facts do not exist. The onus may differ in each case.

\section{Rational Connection}

Proof that no rational connection exists between a challenged act and the legislature's catalogue of powers is difficult. The reason cuts to the heart of both federal and Bill of Rights constitutional review: legislative judgment has been exercised and the legislature has concluded that its enactment is appropriate to further some constitutionally permissible purpose. The court, in striking down the enactment, is squarely substituting its judgment for that of the legislature.

The attacker must demonstrate that the legislative judgment is wholly irrational-that the Act lacks any semblance of reasonable connection to the constitutionally valid purpose. The key question is "whether there is a rational basis for the governmental and legislative judgment exercised in the enactment....".213 To prove invalidity, the answer must be in the negative. "[The court] can only disregard the Act," said Professor Thayer, "when those who have the right to make laws have not merely made a mistake, but have made a very clear one-so clear that it is not open to rational question."214 $\mathrm{He}$ explained:

That is the standard of duty to which the courts bring legislative Acts; that is the test which they apply,-not merely their own judgment as to constitutionality, but their conclusion as to what judgment is permissible to another department which the constitution has charged with the duty of making it. This rule recognizes that, having regard to the great, complex, ever-unfolding exigencies of government, much which will seem unconstitutional to one man, or body of men, may reasonably not seem so to another; that the constitution often admits of different interpretations; that there is often a range of choice and judgment; that in such cases the constitution does not impose upon the legislature any one specific opinion, but leaves open this range of choice; and that whatever choice is rational is constitutional. 215

An example might assist. Assume the existence of a legislatively prescribed length and height for vehicles pursuant to an admittedly valid safety

213 Per Laskin C.J.C. in Reference re Anti-Inflation Act, supra note 5, at 425 (S.C.R.), 497-98 (D.L.R.).

214 Supra note 143, at 144.

215 Id. 
regulation jurisdiction. That law may be attacked by demonstrating that its measures are inappropriate to secure safety. ${ }^{210}$ Alternatively, as a matter of constitutional policy, it might be shown that other regulatory schemes are available, equally effective to accomplish the purpose, but less offensive to interests of the other jurisdiction (or interests protected by a Bill of Rights)..$^{217}$

The presumption of constitutionality throws the onus of demonstrating lack of rational connection on the attacker. How may that burden be discharged?

We are dealing here in opinion-the judgment that some legislative scheme will further some legitimate end. Professor Freund has suggested that the attacker must demonstrate that no body of responsible opinion exists which holds the view that the legislation will further the purpose. He said:

[T]he data are offered not for the truth of the facts asserted but only to establish that responsible persons have made the assertions and hold the opinions which are disclosed. That is to say, the court need not decide whether, for example, filled milk which substitutes cocoanut oil for butter fat is or is not deceptive or detrimental to health; the court need only decide whether there is responsible opinion that it is so. Consequently, the introduction of countervailing evidence would be immaterial. This serves to show the almost insuperable burden placed on the opponents of economic legislation to overcome the effect of data adduced in support. The opponents must show that the opinion in support of the legislation is wholly untenable. 218

Opinions, of course, evolve. Herein lies the great merit of the rational basis test. As responsible opinion moves away from the view that certain legislation is "appropriate to abolish or mitigate the evils believed to exist or apprehended,"219 constitutional support for that legislation weakens; when opinion is set against the legislation, it collapses. Thus, in Bakke, ${ }^{220}$ one witnesses responsible opinion abandoning the view that affirmative action admissions programmes assist elimination of racial inequality without unduly interfering with other Bill of Rights protections-that is as against reverse discrimination. So too in Muller v. Oregon ${ }^{221}$ one sees the demise of any responsible opinion that legislation restricting women's hours of labour is necessary to protect a woman's special physical structure and health.

Legal culture rises and falls with civilization generally. It is not immune from progress and regression in the human community, nor is it merely a mechanical reflection of social evolution. Legal culture is a thought form and a motive force in civilization; it enhances the status of individual dignity and enlightenment in the world order. Constitutional law-especially the Bill of

216 The example is taken from Lane, supra note 10 , at 116 , where he cites Greutner v. Everard (1960), 103 C.L.R. 177 at 189-90, [1960] A.L.R. 550 at 555-56 (H. Ct. of Aust.).

217 Lane, id. at 117, citing Dean Milk Co. v. City of Madison, 340 U.S. 349 at 355-56, 71 S. Ct. 295 at 298-99 (1951).

218 Supra note 98, at 88. Professor Freund expresses reservations concerning this approach, however, in the same article at 88-89.

210 The language is that of Mr. Brandeis as cited in Freund, id. at 89.

220 Regents of the Univ. of Cal. v. Bakke, 98 S. Ct. 2733 (1978).

221 Supra note 98, at 420-21 (U.S.), 326 (S. Ct.). 
Rights constitutional review jurisdiction-catalyzes the process whereby culture and growth in the mind inform the legal order. The rational basis test lives in opinion and feeds on wisdom. It stands as a constant challenge to our culture, inviting opinion to nourish and uplift our legal system-to actualize in practical affairs the great ideals of justice current in our time.

\section{Facts}

Where attacking counsel's allegation is that necessary facts to support a challenged act do not exist or have ceased to exist, his onus is different. He is not dealing in opinion but in fact. Yet the relevant facts are often very strange when viewed from the perspective of ordinary civil and criminal trials. There, the issue is who did what, where and when. By contrast, the attacking counsel in a constitutional case often deals in such facts as whether a crisis exists sufficient to threaten the nation's continuing life, whether a provincial regulatory scheme substantially interferes with the flow of interprovincial trade or whether there exists a Canadian broadcasting system extending beyond the limits of one province or connecting any province with another. That is not to say that constitutional facts are never narrow or precise, ${ }^{222}$ but certain obvious constitutional facts-like the existence of an emergency-bear remarkable resemblance to opinion.

Putting to one side for the moment the strange character of certain constitutional facts, it is useful to ask exactly what standard of proof must be met in order to establish constitutional facts as against the presumption. Canadian case law supplies an answer: "[T]he evidence must be clear and unmistakable."223

While a desire for precision and neatness in academic classification tempts one to reformulate this phrase into the known categories of proof on the probabilities or beyond a reasonable doubt, ${ }^{224}$ this is undesirable.

It is apparent what the judges are saying when they call for very clear and unmistakable evidence. It is not clear, however, whether transposition of civil and criminal evidence categories to a constitutional context will create more problems than are solved. The standard in the constitutional cases is sufficiently high so as to signal caution to the courts in interfering with the legislature. On the whole, it seems better to let classificatory niceties lie-at least while the courts have a workable and useful tool.

In the United States, there is an aspect of the rational basis doctrine

222 See, e.g., CIGOL, supra note 5; and Montcalm Construction v. Minimum Wage Comm'n, supra note 6.

223 CIGOL, id. at 573 (S.C.R.), 468 (D.L.R.). See also Fort Frances Pulp and Power Co., supra note 61, at 706 (A.C.), 635 (D.L.R.); Co-operative Comm. on Japanese Canadians, supra note 38, at 101-02 (A.C.), 585 (D.L.R.); and Kruger, supra note 6, at 112 and 117 (S.C.R.), 440 and 443 (D.L.R.), 383 and 386 (C.C.C.).

224 Professor Buglass takes comfort in this language: "[T]he onus on those challenging the Act would seem to be proof of its invalidity beyond a reasonable doubt." See The Use of Extrinsic Evidence and the Anti-Inflation Act Reference, supra note 107, at 190. 
relevant to the standard of proof for constitutional facts. As previously explained, ${ }^{225}$ government counsel need only show, by the presumption of constitutionality or otherwise, that there is a rational basis upon which the legislature could have concluded that the necessary facts exist. Mr. Justice Beetz referred to this in the Reference re Anti-Inflation Act. ${ }^{226}$ The Supreme Court of Canada employs a similar test in administrative law respecting the leeway that a tribunal is given in finding jurisdictional facts. ${ }^{227}$

Can the rational basis standard be synchronized with the "very clear evidence" test? It appears that it can. The rational basis standard is the hurdle over which government counsel must get when pressed. It is especially pertinent to those strange constitutional facts, like the existence of an emergency, which resemble opinions. The "very clear evidence" test applies to the attacker in all situations.

It seems that each standard can complement and amplify the meaning of the other. Case law developments are now too slim to make profitable a search for greater precision than that. Supposition that conflict exists between the two standards is academic. Both tests are workable and clear; if refinement is needed, the common law's great inductive method will certainly supply it as future cases arise.

\section{CONCLUSION}

Canadian constitutional law has come to the crossroads; it has taken a decisive turn. Abstract jurisdictional conflicts want to recede into Canadian history. The road forward leads in another direction, and promises a transformation in constitutional litigation. Curial emphasis now marches toward narrowing and crystallizing constitutional issues with relevant facts, policies, and opinions. Chief among the techniques used to quicken this movement is the presumption of constitutionality.

The presumption of constitutionality, especially as applied in an evidentiary sense, stands as a great and constant warning to attacking counsel concerning matters of fact. All facts relevant to support his case must be brought before the court. Failure to do so will concentrate the presumption's force on that issue. Counsel refrains from complete presentation of all factual issues at his peril; all ambiguous questions of fact will be presumed in favour of the government.

Furthermore, the government may not seek security in the presumption's shadow to conceal relevant facts. The court has deployed impressive factgathering devices and is willing to conduct its own researches. Where the government alone is in possession of crucial facts, the presumption may be reversed to compel presentation of those facts before the court. The end of

225 See text accompanying note 97, supra.

228 Supra note 6. See text accompanying note 106, supra.

227 See, e.g., Jacmain v. A.G. Can., [1978] 2 S.C.R. 15, 81 D.L.R. 1, 78 C.L.L.C. 13, especially per Dickson J. dissenting on another point; and C.U.P.E. v. N.B. Liquor Comm'n, [1979] 2 S.C.R. 227, 97 D.L.R. (3d) 417. 
all this is construction of a full, useful, and concrete factual record; the means is an evidentiary presumption of constitutionality.

Simultaneous with the heightened importance given to facts, the judiciary has assumed an aroused sense of respect for making sound choices in matters of policy. The constitutional review jurisdiction requires statesmanship and sophistication in the power allocation required by federalist disputes and the power limitation required by Bill of Rights disputes. Appreciation of the difference between constitutional policy in constitutional review and legislative policy in law-making allows the court security in policy formulation. The limits of the curial jurisdiction assume clearer definition; the judges' responsibility to discharge that jurisdiction stands out in bolder relief.

So too, the rational basis doctrine advances the new step of constitutional law. It offers a refined and balanced means of informing constitutional law thinking with the most civilized opinion that our culture can produce. Constitutional law can more readily assimilate growth in the mind generally; it can further the advance of enlightenment in the legal order. The presumption of constitutionality throws a spotlight on this process and quickens its development.

These are immensely important developments requiring careful analysis and nurture. Much attention herein has been concentrated on technique, but not because the technique of the presumption of constitutionality is an end in itself. Concentration on technique assists in breaking down the broad issues of constitutional law while allowing the issues themselves to remain plainly in view. "Only the exhaustive can be truly interesting,"228 said Thomas Mann. In the present matter one may add, "and significant."

Finally, it is useful to remember that the presumption of constitutionality doctrine is a self-effacing technique. Its greatest significance and guiding principle lies in the push that it gives towards completeness and crystallization of constitutional issues. As constitutional issues achieve adequacy and fullness in presentation, the presumption will diminish greatly in importance. It will only have succeeded completely in its technical mission at the moment when need for it disappears.

228 The Magic Mountain, trans. Lowe-Porter (London: Secker and Warburg, 1961) at vi. 